\title{
Scenarios of availability of water due to overexploitation of the aquifer in the basin of Laguna de Santiaguillo, Durango, Mexico
}

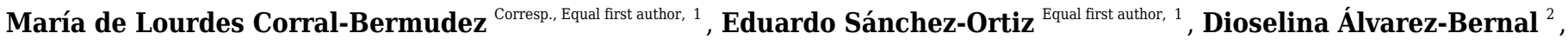 \\ Martín Omar Gutiérrez-Montenegro ${ }^{1}$, Erika Cassio-Madrazo ${ }^{1}$ \\ ${ }^{1}$ Centro Interdisciplinario de Investigación para el Desarrollo Integral Regional Unidad Durango, Instituto Politécnico Nacional, Durango, Durango, México \\ 2 Centro Interdisciplinario de Investigación para el Desarrollo Integral Regional Unidad Michoacán, Instituto Politécnico Nacional, Jiquilpan, Michoacán, \\ México \\ Corresponding Author: María de Lourdes Corral-Bermudez \\ Email address: mcorralb1000@alumno.ipn.mx
}

Background. The importance of water to life is unquestionable. Most of the fresh water we use for daily activities comes from the aquifers which in many cases due to misuse are over-exploited and at risk. This article studies the aquifer that appeared in Laguna de Santiaguillo basin; it should be noted that the most important economic activity in the basin is agriculture. Methods. By analyzing vector and demographic information, using GIS and with some field trips, the impact and risk on the level of disposition in every microbasin that forms the basin were determined. Results. The different modeling scenarios demonstrate that the basin and sub-basins that conform Santiaguillo are overexploited. Discussion. The volumes concessioned are of such magnitude that they generate a condition of vulnerability to the activities of the basin and sustain the overexploitation conditions of the aquifer. 


\section{Scenarios of availability of water due to overexploitation of the aquifer in the basin of Laguna de Santiaguillo, Durango, Mexico.}

María de Lourdes Corral-Bermúdez ${ }^{1}$, Eduardo Sánchez-Ortiz ${ }^{1}$, Dioselina Álvarez-Bernal ${ }^{2}$, Martín Omar Gutiérrez-Montenegro ${ }^{1}$, Erika Cassio- Madrazo ${ }^{1}$

${ }^{1}$ Centro Interdisciplinario de Investigación para el Desarrollo Integral Regional Unidad Durango, Instituto Politécnico Nacional, Durango, Durango, México

${ }^{2}$ Centro Interdisciplinario de Investigación para el Desarrollo Integral Regional Unidad Michoacán, Instituto Politécnico Nacional, Jiquilpan, Michoacán, México

Corresponding Autor:

María de Lourdes Corral-Bermúdez ${ }^{1}$

Sigma 119, Fracc. 20 de noviembre II, Durango, Dgo, 34220, México

Email: mcorralb1000@alumno.ipn.mx

Abstract.

Background. The importance of water to life is unquestionable. Most of the fresh water we use for daily activities comes from the aquifers which in many cases due to misuse are over-exploited and at risk.

This article studies the aquifer that appeared in Laguna de Santiaguillo basin; it should be noted that the most important economic activity in the basin is agriculture.

Methods. By analyzing vector and demographic information, using GIS and with some field trips, the impact and risk on the level of disposition in every micro-basin that forms the basin were determined.

Results. The different modeling scenarios demonstrate that the basin and sub-basins that conform Santiaguillo are overexploited.

Discussion. The volumes concessioned are of such magnitude that they generate a condition of vulnerability to the activities of the basin and sustain the overexploitation conditions of the aquifer.

\section{INTRODUCTION}

Water is an indispensable resource to almost all life in the world; one of the characteristics of this element is its potentiality to be renewable. The availability of superficial fresh water is calculated between 9,000 and $14,000 \mathrm{~km}^{3}$, and just $4,200 \mathrm{~km}^{3}$ are available for human consumption (Cantu, 2012). Two percent (2\%) of all fresh water is frozen in the polar ice caps. On the other hand, groundwater is stored at a depth of $1000 \mathrm{~m}$, representing $0.5 \%$ availability. This means a greater availability than that in rivers and the sea (Fernandez, du Mortier, 2005).

The availability of fresh water in Mexico is about $475 \mathrm{~km}^{3}, 63 \mathrm{~km}^{3}$ of this water is in the underground, and the other $412 \mathrm{~km}^{3}$ is surface water (Dominguez, 2011). The annual average 
rainfall in Mexico is of a volume of $1511 \mathrm{~km}^{3}$, which classifies Mexico as a country with low water availability (Fondo para la Comunicacion y Educacion Ambiental, 2006).

The term average annual availability of surface water in a hydrological basin in its natural state (without water use) is the limit of the annual average volume of water that can be granted or assigned in a sustainable manner. On the other hand, in a basin in which some use is already made, the average annual availability of surface water is the portion of that limit that continues to be available for concessioning (Silva et al, 2013).

The concept of availability of the NOM-011-CNA-2000 has a juridical-administrative or regulatory meaning, since it has the purpose of defining the existence of volumes of water susceptible to being concessioned in a basin, without affecting the volumes previously granted ( Silva et al, 2013).

The availability of water is threatened due to some economic activities of great importance such as industry and agriculture which require large volumes of fresh water to be carried out. As a result, aquifers suffer overexploitation.

As Custodio states: "an aquifer is considered to be overexploited, or at risk of overexploitation, when the sustainability of existence is an immediate threat as a consequence of abstraction being grater, or very close to, the annual mean volume of renewable resources, or when abstraction may produce a serious water-quality deterioration" (Custodio, 2002).

At a global level, aquifers present a serious threat due to both pollution and overexploitation caused by urbanization, industrial development, agricultural activities, and mining ventures (World Bank, 2002).

In Mexico, the water administration has caused that 106 of the 653 aquifers be overexploited and some of them show deterioration in the quality of groundwater, data expressed by experts during the Second National Colloquium "Groundwater in Mexico" carried out in the senate (Reforma, 2015).

Groundwater is one of the most important natural resources, the overexploitation of aquifers generates that the salinity of groundwater increases and continues to threaten the viability of agriculture (Khenzzani, Bouchemal, 2018).

When an aquifer is declared overexploited, there are some actions and factors that should be considered, some of them are the legacy and to inform the population of the conditions in which the aquifer is found, as well as the remedial actions that can be carried out for the recovery and recharge of the aquifer.

All the rules, issues and procedures involve peasants, sellers and groups with agriculture interests as well as politicians, legislators and judges. They control the access to the means of production and establish the economic and social interests in relation to the natural, technological and human resources. But they also install the legitimate forms to transfer the resources either by allocation, interchange, sale or heritage (Moreyra et al, 2012). 
74 The capitalist-neoliberal model of food production is incapable of solving the problems of food security. The control, form and conditions under which unregulated capital operates in the world diet, activate the conditions for increasing insecurity, both in terms of food quantity and quality (Altieri, 1999).

Modern agriculture, with intensive abuse of industrial chemicals and bad distribution of water, has a negative impact on the environmental and human health. Soils, lakes, rivers and groundwater suffer the impact of pollution (Martínez, 2009).

There are some studies that demonstrate the risk of an overexploited aquifer. An example of this is the case of the aquifer of Disi in Jordan. The study reveals that the environmental consequences of groundwater extractions generate dropping water levels, mobilization of some salty water bodies in geologic units connected vertically with Disi aquifer such as Khureim Formation and irrigation return flow waters with their high salt contents, biocides, and fertilizers concentrations (Salameh et al, 2014).

\section{The aquifers in Mexico}

Mexico is divided into 653 aquifers, of which 448 national aquifers are in a condition of availability, as of 2016, 105 overexploited aquifers were reported in the country, considering overexploitation based on the extraction / recharge ratio (Statistics on Water in Mexico, 2017 ) (http://sina.conagua.gob.mx/publicaciones/EAM_2017.pdf).

The north and center of Mexico, have the largest amount of overexploited aquifers, since there is more population but less surface water, so that more groundwater is used (Diaz et al, 2013).

A poor use of resources places the population in an imminent risk. It is important to consider that the risk is the vulnerability that is conjugated with the threat, taking into account that nature is not generating said risks, but the social conditions themselves.

There is a discussion of socioeconomic vulnerability regarding the degree to which social classes are differently at risk. Recognizing the conditions of socioeconomic vulnerability as a generator of risk and disaster has a political dimension: it implies the acknowledgement that in the states of risks and disasters there is a political and social responsibility, which refers to the notions of environmental and spatial justice (Campos, Toscana, Campos, 2014).

It is important to emphasize that disasters are not only the products of threats, they are consequences of the environmentally unsustainable economic development model from which some sectors benefit, to the detriment of others, at all scales: global, national and regional (Campo, Toscana, Campos, 2014).

Description of the area of study

Location of the basin of the Santiaguillo Lagoon

The endorheic basin of Santiaguillo Lagoon is located to the north of the hydrological region no. 11 of the Presidio and San Pedro rivers, with a surface of 2,542.16 km2. This basin partially covers 
113 the municipalities of Canatlán, Coneto de Comonfort, El Oro, San Juan del Río, Santiago 114 Papasquiaro and Nuevo Ideal (CONAGUA, 2011).

115 "Santiaguillo" is the southeast region from the route followed by the migratory birds that come 116 from Alaska and Canada. These birds nest in Santiaguillo, which is why this site is considered one 117 of the 30 most important wetlands. International organizations place the basin in an under-pressure 118 water condition derived from the underground extraction, the pollution and the way to address the 119 management of water and drought (CONANP, 2012).

\section{Topographic profile}

121 Tracing a cut from south to north, the profile starts from a maximum altitude of almost 3,200 m.a.s.l. in the southeast zone, characterized by an accidental topography with steep slopes in the first $15 \mathrm{~km}$. After that, there is an extension of $30 \mathrm{~km}$ where the slope is very small and finally there is an increase in altitude close to 2,000 m.a.s.1. in the north part.

\section{Orographic characteristics}

126

127

128

129

130

131

132

133

134

135

136

137

138

139

140

141

142

143

144

145

146

147

148

149

The zone belongs to the physiographic province of the "Sierra Madre Occidental", and the subprovinces are the Gran Meseta and the Cañones Duranguenses [Durango's ravines], which has its origin in the southern part to the west of the territory; the rest is described as mountains and plains of Durango (Figure 1).

The basin is located inside a "graben", that is, a depression limited on both sides by raised faults, where the terrain of the internal part has sunk because of internal forces (Nieto- Samaniego et al,2012), the area is characterized by the relief of the north and south zone that the surveys perfectly close the graben thus giving origin to the endorheic sub-basin (Figure 2). Nieto describes the site as: "The Santiaguillo graben forms the northwestern part of the regional San LuisTepehuanes fault system, which is located between the Sierra Madre Occidental and the physiographic Mesa Central. In the region of Santiaguillo graben, we identified eight lithostratigraphic units with ages from Eocene to Quaternary" (Nieto Samaniego et al, 2012).

Figure 1. Topoform system map

Physical aspects

Source: Own elaboration

Weather

In the valley of Santiaguillo, two types of climates are identified: dry semidesert (BS) and a series of mesothermal or temperate climates with dry period in winter $(\mathrm{Cw})$. The temperature ranges from 8 to $18^{\circ} \mathrm{C}$, with an average precipitation of 300 to $800 \mathrm{~mm}$ (INEGI, 2010).

Table 1 shows the extension of each type of climate, to get the classification of weather it was used the köppen classification.

Table 1. Types of climate and its extension in the sub-basin

Source: own elaboration with vector information of INEGI (For its acronym in Spanish, National Institute of Statistics and Geography) 
150

151

152

153

154

155

156

157

158

159

160

161

162

163

164

165

166

167

168

169

170

171

172

173

174

175

176

177

178

179

180

181

182

183

184

185

\section{Hydrography}

Figure 2. Hydrograhic Map Of Laguna de Santiaguillo Basin Source: own elaboration with vector information of INEGI

The map of figure 2 shows the detailed hydrography, which allows to understand the behavior shown in figure 3, where hydrology is presented by microbasins.

In this study case it is proposed the use of microbasins as a reference to the specific surface exploitation areas.

Figure 3. Map of hydrology surface and division in micro-watersheds

Source: Own elaboration with vector information of INEGI

The most important micro-basin in the surface is located to the north, where the Tinajuelas stream is formed, this is the main runoff and it has its origin in the northern mountain range ending in the northern body of the Santiaguillo lagoon.

The streams of San Antonio, Grande, Hondo, San Francisco and the Tinajitas are its tributaries from the northeast. From the northeast area are also the streams: Los Alamos, Palos Colorados, Colorado and Salto de San Lucas. In this micro-basin it is also located the Zeta stream that rises in the northeast area and empties directly into the north lagoon; the stream of El Toboso has its origin in this area and it is the main contributor of water to the Zeta stream, which in turn joins the Tinajuelas at the mouth.

The Gato stream has its origin in Santa Rosa hill which passes through the side of the town of Nuevo Ideal and flows into the north lagoon. The Candado stream and Guatimape river or the Molino are born in the mountain range of Epazote.

Its runoff ends in two bodies of water located in the central part of the basin aligned from north to south, the topographic configuration around them is composed of areas of reduced extension, high and steep, the largest are located towards the southwest and northeast of the sub-basin; the topography of this site corresponds to mountain ranges of El Epazote, San Francisco and San Miguel, the altitude ranges fluctuates around 3000 m.a.s.1., the average elevation is 2,160 m.a.s.1. forming a valley that has allowed the development of important productive activities (CONAGUA, 2011)

The streams in order of importance are Tinajuelas, Guatimape, Tejamen, El Gato, El candado, Torunos, Las Jarillas and El Trebol; these streams feed the northern lagoon body that has perennial water. On the other hand, El Colorado, La Tinaja, Viborillas, Ojo de Lobo and Los monos feed the southern lagoon which has an intermittent behavior.

The streams Alisos, Gigantes and Seco lead into the Astilleros stream, which is another principal slope of the area. In the east area, there stand out the streams Hondo, Grande, Las Jarillas and Coyotillos.

All the runoff forms the municipality of Nuevo Ideal and spills its waters into the northern lagoon. 
186 In the municipality of Canatlán, the streams of La Soledad, Los Ladrones, Claveras and La Tinaja

187 have its slopes in the south lagoon.

188 Surface lithology

189 The Laguna de Santiaguillo basin is made up of alluvial soils, which are in the plain areas, and 190 cover $40.95 \%$. These soils are known as alluvial fans, they are located next to mountainous belts 191 and they are materials transported by water; their size varies from clay to thick gravels, ridges and 192 blocks (Molina Garza, 2013).

193 Rhyolite- acid tuff rocks cover $40.45 \%$ of the area and are characterized by volcanic rocks composed of quartz and alkali feldspar. Eleven percent (11\%) of the surface rock is constituted by lacustrine sedimentary media which allows the presence of detrital and biodetritic, chemical, biochemical and organic sediments; these are located mainly in the bed of both lagoon bodies, determining their important age (Ayala, 2010).

The rest of the geological composition of the area is Tufa-acid 3.13\%, andesite $2.5 \%$ (volcanic rock), conglomerate $1.37 \%$ (sedimentary rock), wind $0.25 \%$ (the accumulation of materials has its origin in the wind), basalt $0.14 \%$ (volcanic igneous rock), intermediate tuff $0.06 \%$ and tonalite $0.05 \%$ (plutonic igneous rock), the sub-basin distribution presents the most representative values.

\section{$\underline{\text { Soils }}$}

203

204

205

206

207

208

209

210

211

212

213

214

215

216

217

218

219

220

221

222

The soils that are distributed in the basin are of Vertisol type with $25.83 \%$ of the total area and it refers to a type of clay soil, heavy and fine texture, it is impermeable, susceptible to floods. It is hard to dry and tends to be a floor that turns or flips. Their presence reveals the lacustrine formation processes in the basin from the erosions of the middle and upper basin areas, depositing by dragging in the parts where the runoff speed is reduced due to the slope. It is present in temperate and warm climate, the vegetation on this type of soil in the basin consists of pastures and bushes.

Lithosol is present in $23.9 \%$ of the sub-basin and due to its acid characteristics and its thickness of about $10 \mathrm{~cm}$ of rock or limestone (tepetate), it is mainly used for grazing since it is not suitable for crops. The regosol type covers $19.33 \%$ of the sub-basin present on the west slope under the pine forests, it does not have horizons and it is a very permeable soil.

Solonchak is a type of salic soil characterized by being very permeable and it covers $8 \%$ of the territory of the sub-basin it is particularly identifiable in the unflooded lagoon beds. According to the vector data of the INEGI the water bodies do not apply in the matter of soil; their occupancy is $4.75 \%$; however, when the south lagoon dries, it reveals this type of soil on its bed (INEGI, 2004 and Silva M, 1981).

Regarding the texture of the soil, the sub-basin presents an average texture of $56 \%$ of its surface, followed by a fine texture with $30.46 \%$; the coarse texture occupies $9.01 \%$ of the territory; the remaining $4.75 \%$ belongs to the southern lagoon and there is no data available regarding its texture (INEGI, 2010) (Table 2).

Table 2. Soil surface by texture of the sub-basin 
Ground cover

225 In the sub-basin of Santiaguillo, there is vegetation of pine forests, most of it is located in the area 226 of the plateau occupying $20.75 \%$ of the area, the forest of oak-pine occupies $3.5 \%$ and its 227 distribution is in the eastern area, 2.43\% oak forest is found in certain areas to the north, southeast 228 and south of the sub-basin. The pine-oak forest occupies $1.32 \%$ and extends from the north to the east of the mountain range of Coneto.(INEGI, 2010)

The area studied has three types of grassland: $10.45 \%$ of the surface of the Santiaguillo valley presents natural grassland, $3.47 \%$ induced pastureland and $2.58 \%$ is halophilic grassland. Three point ninety-four percent $(3.94 \%)$ of the surface is crasicaule scrub, the bushes of fleshy stems such as nopales, Opuntia cactaceae and others are dominant (INEGI, 2010).

Description of the aquifer

The "Valle de Santiaguillo" aquifer has an average annual recharge of 50.7 million $\mathrm{m} 3$ / year, against a natural discharge of 8.0 million $\mathrm{m} 3$ / year. The concessioned volume of groundwater is 60 million $\mathrm{m} 3$, and according to the CONAGUA it is in a deficit of -15.472461 million $\mathrm{m} 3$ / year (CONAGUA, 2009).

With regard to the administrative situation, it is active for exploitation and use of national waters and the aquifer in its entirety is free of delivery (CONAGUA, 2009).

According to the decree published on December 31, 1999, in the "Diario Oficial de la Federación", 3 zones are established for the availability of the aquifer. The 1039 belonging to the municipality of Nuevo Ideal and located in the area of availability 6, 1001 of the municipality of Canatlán within zone 6 of availability and 1032 of Santiago Papasquiaro within the area of availability 7.

247 CONAGUA establishes that the aquifer is in a state of vulnerability with an index value of 7 , which in the scale refers to a high contamination vulnerability (CONAGUA, 2009)

$\underline{\text { Economic and social aspects }}$

Demography

According to the results of the INEGI census and counting the 151 locations located within the basin, in a period of 10 years (2000-2010), 102 locations of the 131 had a decrease in their population; 41 of them showed an increase and 9 maintained an equal number of inhabitants 254 (INEGI, 2010).

Of the 31,967 inhabitants of the basin, 21,091 (66\%) live in rural areas (towns with less than 2500 256 inhabitants) and the rest live in the town of Nuevo Ideal with a population of 10,876 inhabitants 257 (34\%) (INEGI,2010).

258 The analysis of the population pyramid reveals that the birth rate is higher in males than in females. 259 To the 2049 children registered under 2 years old, 965 were female and 1084 were males, the 
260

261

262

263

264

265

266

267

268

269

270

271

272

273

274

275

276

277

278

279

280

281

282

283

284

285

286

287

288

289

290

291

292

293 difference remains constant until the age of the majority is exceeded since the range of 18-to-24year-old women $(2,076)$ exceeded the number of men $(2,026)$ due to immigration seeking better employment opportunities. The third age (60 years and older) is $12 \%$ (3,872 individuals) of the total population (INEGI,2010) (Figure 4).

\section{Access to education}

Regarding the literacy of the 24,123 people who were examined in this area, 1,952 persons (8\%) do not attend school, in this category small children who are not yet of school age are omitted, including children over five years and adolescents up to 14 years old. 1,621 persons (7\%) of the individuals whose ages vary between 15 and 24 years attend school, while 4\% (919 people including children and adolescents ranging from 8 to 15 years old, and adults) were considered illiterate. Nevertheless, the figures indicate that almost $70 \%$ of the population has unfinished education, and in many cases incomplete basic education.(INEGI,2010)

$\underline{\text { Economic conditions }}$

Of the 13 largest locations in the basin (20,363 inhabitants), only 35\% (7,062 inhabitants) are economically active. The first income for the families of these communities comes from men since $80 \%$ of the total economically active population is male (INEGI,2010).

Fifty-eight percent (58\%) of the total population (18,593 inhabitants) are entitled to medical care and health services in some public or private institution, $41 \%$ of them do not to have the right to receive any medical attention, while a minority of $1 \%$ did not provide this information (INEGI,2010).

\section{Access to public health services}

Of the results obtained by the sample of the thirteen locations with significant populations, $66 \%$ have medical services and 34\% (20,363 inhabitants) do not (INEGI,2010).

The total number of households in the 151 locations is 7,879 , of which 6,122 are headed by a male or head of a family (78\%) and 1,757 are female-headed (22\%) (INEGI,2010).

The households in which the head of family is male account for $81 \%$ of the total population, which corresponds to 25,690 inhabitants; the households whose head of family was a woman are $19 \%$ (5,959 inhabitants) (INEGI,2010).

\section{$\underline{\text { Housing conditions }}$}

Of the 11,649 homes surveyed, 11,545 homes are private and only 7,959 (68\%) are inhabited dwellings; the density is 4 inhabitants per house (INEGI,2010).

Of the 7,879 inhabited private homes, $96 \%$ have a different floor than the land and only $4 \%$ have a dirt floor; $70 \%$ have 2 or more bedrooms; $90 \%(7,080)$ of the houses are made up of 3 or more rooms (kitchen, bathroom, living room, bedroom, etc.) (INEGI,2010).

Peer) reviewing PDF | (2018:08:30469:2:2:NEW 14 Mar 2019) 
294 Ninety-eight percent (98\%) of the houses have electricity service, $94 \%$ have piped water service, $29591 \%$ have a toilet, and 84\% have drainage service connected to a municipal network, $80.3 \%$ of the 296 total houses studied in this analysis have all of the aforementioned services (INEGI,2010).

297

298

299

300

301

302

303

304

305

306

307

308

309

310

311

312

313

314

315

316

317

318

319

320

321

322

323

324

325

326

327

328

329

330

$\underline{\text { Marginalization index }}$

According to the data provided by CONAPO (Comisión Nacional de Población) in 2015, the municipality of Canatlán showed an index of marginalization of -0.822 , Nuevo Ideal $-1.001 \mathrm{y}$ Santiago Papasquiaro -0.676, which places the basin of the Laguna de Santiaguillo in a low degree of marginalization (CONAPO,2015).

Figure 4. Population pyramid of the Laguna de Santiaguillo basin

Source: own elaboration with 2010 census information of INEGI

The aim of this article is to evaluate the availability of water in Laguna de Santiaguillo basin derived from the overexploitation of the aquifer to propose the main ideas to get some sustainable mitigation measures.

\section{MATERIALS AND METHODS}

To get the characterization of the sub-basin, the data employed was vector and demographic obtained from the National Institute of Geography, Informatics and Statistics (for its acronym in Spanish INEGI) and it was processed using geographic information systems. The information of the hydraulic infrastructure of the principal rivers in the zone, the public register of the rights of water and some of the vector data were obtained from the National Commission of Water (for its acronym in Spanish CONAGUA). Meteorological information was collected from the register of National Meteorology Service (for its acronym in Spanish SMN) (http://smn.cna.gob.mx/es/informacion-climatologica-ver-estado?estado=dgo) and the spatial analysis was made using the computer package Arcgis 9.3.

In the field, the outline of the sub-basin in the plane zones was studied by giving a terrestrial travel verifying the watersheds corresponding to the limits of the sub-basin. A GPS Garming Oreon 550 was used, along with a UTM coordinate system with a Datum WGS84.

Each micro-basin was overlaid by layers putting together the natural data that influences the water availability. The vector layers of hydraulic infrastructure, roads, locations and Agricola zone were used to get the anthropic factors and the influence they have in the zone following water availability. This allowed to attain knowledge of the natural dynamic and social conditions about the water use and cycle in the zone.

A hydrological balance was carried out at micro-basin level using the methodology indicated by the NOM-011- CONAGUA-2015 and the manual given by the Mexican Institute of Water Technology (IMTA, for its acronym in Spanish).

The Nom 011 established the average annual availability of national waters in hydrological basins and in aquifers. The method shall be considered as the minimum mandatory technical requirement and does not exclude the additional application of complementary methods or the more 
331

complicated and precise cases, when the available information allows it, in which case the Commission shall review together with the users and determine which are the results that prevail.

The Norm basically signalize the availability annual average of surface water in the basin, annual average volume of wring of the basin towards waters down, availability annual average of water from the subsoil in an aquifer.

To determine the main channel at the outlet of the hydrological basin, by means of the following expression:

Availability annual average of surface water in the basin $=$ Annual average volume of the basin runoff towards water down - Current Annual volume committed water down

\section{Equation 1}

The mean annual runoff volume of the basin downstream of the site of interest is determined when applying the following expression:

Annual Average volume of runoff of the basin towards waters down $=$ Annual average volume of runoff from the upper waters basin + Medium Volume annual runoff natural + Annual volume of returns + Annual volume of imports - Annual volume of exports - Annual volume of extraction of superficial water

- Annual average volume evaporation in reservoirs - Medium volume annual variation storage in embalses

Equation 2
Availability annual average of water from the subsoil in an aquifer $=$ Total recharge annual average - Discharge natural engaged - water extraction groundwater

Equation 3

Combined with the regulations, the runoff coefficients given in the manual were used: evaluation of water resources, elaboration of water balance integrated by river basins

Derived from the runoff coefficients, the volumes that infiltrate, evaporate and drain are evaluated.

Starting from the scenario given by the balance of surface and groundwater other scenarios were modeled by simulating the reduction of extraction to find the ideal conditions.

The analysis was based on the concept of natural runoff. Based on the above, the relative availability understood as the ratio between availability and total human and natural demand was determined. Under the usual criteria, a relative availability under 1.4 is classified as a deficit, from 1.4 to 3.0 is qualified as equilibrium, from 3.0 to 9.0 as availability and greater than 9 as abundance.

In this study case it is proposed the use of microbasins as a reference to the specific surface exploitation areas, they could be linked in an specific area in the aquifer. Even as it is just one 
364

365

366

367

368

369

370

371

372

373

374

375

376

377

378

379

380

381

382

383

384

385

386

387

388

389

390

391

392

393

394

395

396

397

398

399

400

401

aquifer, there are some areas in which the pressure is higher than in other areas, so it is propose the needed to regionalizer with the use of the microbasins.

To delimit the microwatersheds their areas were determined, and the corresponding cuttings were made in all the vector layers to generate the detailed cartography.

From the topographic mapping analysis, it was determined that the lake surface reaches $8 \%$ of the total basin

The water availability criteria used are those presented by Shiklomanov (Table 3).

Tabla 3. Levels of water availability

Fuente: Shiklomanov, Igor, World Water resources at the beginning of the 21 st century, PHIUNESCO,2002

\section{RESULTS}

$\underline{\text { Land use }}$

According to INEGI'S vector data 2012, the sub-basin presents the following land use (Figure 5): $51.08 \%$ of the area has a forest, livestock or agricultural use, this area covers the plains region of agricultural use; $17.54 \%$ is considered for irrigation farming is at the largest area found in the north. In the western zone, there is the Tejamen dam, where an extension of irrigated farmland originates and reaches the central area of the sub-basin, covering the needs either by running water or by the series of wells found in the zone according to the vector data of the REPDA, in the same way the dam of El Candado presents a portion of irrigated farmland by water rolled in combination with wells of water in the area, $82.46 \%$ is seasonal agriculture (Table 4).

Figure 5. Land use for agriculture in the sub-basin

Source: Own elaboration with vector information of INEGI

To obtain the map of figure 6 the information was used, the agricultural information provided by INEGI was used, the information used corresponds to the year 2012 Hydrological balance of surface water

The determination of the relative availability at the micro-watershed level reflects a regionalized manner of the different pressure conditions to which the resource is subject due to human activity.

All the determinations were based on the volumes concessioned and registered in the Public Registry of Water Rights of the National Water Commission; therefore, the balance reflects only the administrative condition and not necessarily the real one: however, in the absence of data regarding the real extractions of the surface water volumes used and those extracted from groundwater. This study allows us to evaluate the condition of vulnerability of the basin based on the availability of the resource due to the way in which use is regulated.

In the micro-watersheds that contribute their runoff to the northern part of the Santiaguillo lagoon, relative availability is obtained with deficit conditions in the micro-basins: "Presa Tejamen" to the east of the lagoon body and "Torunos" located to the west, following the other micro-basins exert a little pressure over the water resource. Abundance conditions are only found in the micro-basin located upstream of the Dr. Castillo del Valle and La Redonda dams, which due to their natural 
402 conditions are important generators of water that are not used. Moreover, in the case of La 403 Redonda there are conservation actions in the upper basin.

404 In the micro-basins that provide water to the southern part of the Laguna de Santiaguillo with 405 significantly smaller extensions, with human presence in practically all of them and with a high 406 pressure on a very limited resource, the general conditions of relative availability are deficit.

407 The results of the surface water balance (Table 5), in combination with the groundwater balance 408 (Table 6), describe the heterogeneity of the basin that favors differences in the amount of rainfall 409 within it. According to the calculations made, an annual total precipitated volume of 1,416 million 410 cubic meters is estimated.

411 The texture of the soil and the combination with the differences in the vegetation cover of the zone 412 propitiate a variation in the drained volume, the coefficient of average draining that was 413 determined is $10.45 \%$.

414 The average annual volume of runoff was estimated at 341 million cubic meters. The Gato, 415 Tejamen and El Candado micro-basins present higher runoff coefficients due to the areas they use 416 for agricultural activity.

417 The surface lithology in combination with the types of soil and its texture allow an average 418 infiltration percentage of $1.84 \%$ of the total precipitation, the total annual average volume 419 infiltrated to the aquifer was calculated in 29.18 million $\mathrm{m}^{3}$. The infiltration is attributed to the 420 types of soil and rock present in the micro-basin, it was observed that areas with less infiltration 421 have a combination of soils of the vertisol or solonchak type and tuffs.

422 Volumes of concessioned water

423 The area studied presented different volumes of surface water concessions, highlighting the El 424 Candado, Tejamen and Las Jarillas micro-basins with the most important hydraulic works and 425 surface concessions in the area.

426 Based on the results of the integral hydrological balance, it was observed that the micro-basins are 427 capable of capturing sufficient rainfall to satisfy the surface granted by CONAGUA; however, two 428 of them showed a deficit since their contribution is not enough to provide the volumes awarded. 429 Specifically in relation to the El Candado micro-basin, the results obtained showed surface water 430 availability conditions.

431 The average runoff in the basin is 135.79 millions of $\mathrm{m}^{3} /$ Year, the shallowness of the superficial 432 and underground natural reservoirs in the sub-basin favors the evaporation of 81 millions of $\mathrm{m}^{3} /$ 433 year. Added to this the geographical conditions of the sub-basin are short-term streams and a quick 434 discharge to the body of water called the Santiaguillo lagoon, only 16.26 millions of $\mathrm{m}^{3}$ have been 435 concessioned in the middle and upper basin. With this, the surface availability is 38.53 millions of $436 \mathrm{~m}^{3}$, thus resulting in a relative availability of 1.4 considered as deficit (Comisión Nacional del 437 Agua, 2011).

438 It was estimated that the natural surface availability per capita (amount of water that exists) can be 439 allocated to their economic activities, which was obtained by dividing the drained volume between 
440 the number of inhabitants. Most micro-basins showed levels ranging from average to high. Based

441 on this data per person, the quantity of water used in different activities is obtained over 6,000

442 cubic meters on an annual basis per inhabitant.

443 The availability of development was determined by calculating the difference between the drained

444 volume with the surface water concessioned, to know if they have the capacity to provide surface

445 water to cover future demands in economic activities such as livestock or agriculture. The micro-

446 basins that provided sufficient surface water to satisfy demands in terms of agriculture and

447 livestock are El Candado, Guatimapé, Viborillas and Ojo de Lobo whose values of excess drained

448 water of the volume concessioned propitiate this condition.

449 Hydraulic Infrastructure

450 In the area, there are three small storage dams for agricultural irrigation use : La Redonda, Tejamen 451 and Dr. Castillo del Valle. They have storage capacities of 7.0, 3.0 and $0.8 \mathrm{Hm}^{3}$.

452 There is a significant number of deep wells that according to the public registry of water rights 453 (REPDA for its acronym in Spanish) amount to 1,958 works in the cut to 2011 (CONAGUA, 454 2011).

455 Hydrological balance of groundwater

456 Volume of concessioned groundwater

457 The aforementioned conditions also influence that the Santiaguillo Valley aquifer receives an 458 average annual recharge of 30.42 millions of $\mathrm{m}^{3}$ / year with a committed natural discharge of 23.04 459 millions of $\mathrm{m}^{3} /$ year, mostly by evapotranspiration. The aquifer presents concessions of 90.69 460 millions of $\mathrm{m}^{3}$, almost three times the capacity of the average annual recharge, which favors 461 overexploitation, so that the underground deficit is 83.32 millions of $\mathrm{m}^{3} /$ year (CONAGUA, 2011, 462 2002).

463 The number of underground extraction points counted for this study is 1,996 wells, distributed 464 throughout the lower part of the basin around the lagoon bodies. The concessions were 465 concentrated in Table 4, converting agricultural use as the main groundwater use with 1,329 wells 466 and over 5 million $\mathrm{m}^{3}$ of annual concessions.

Table 4. Number and volume of the underground sources granted

Source: Own elaboration with information of the Public Register of water rights, of the National Commission of water.

The use of groundwater in the Laguna de Santiaguillo basin has its greatest application in agriculture; the percentages of the use are showed in the figure 6. 
476 was observed in the micro-basins located to the west and north, exceeding more than five times its 477 recharge capacity.

478 Given the condition of overexploitation of the aquifer and its limited recharge conditions, the 479 modeling of scenarios was carried out, which allowed to observe whether the expectations of 480 resolving the vulnerability of the basin are reachable or not.

481 To do this, the 5 scenarios were modeled making a reduction of extractions:

482 Socio-environmental vulnerability assessment

483 Delimitation of micro-basin

484 For the purposes of this investigation, the basin area was divided into 13 micro-basins of the 485 mentioned streams, as well as the lagoon bodies (Figure 7).

486 From the topographic mapping analysis, it was determined that the lake surface reaches $8 \%$ of the 487 total basin and, according to this, the northern lagoon that covers only $81.38 \mathrm{Km}^{2}(3.2 \%)$ is fed 488 with the runoff of $1905.34 \mathrm{Km}^{2}$, that is to say, $75 \%$ of the surface of the sub-basin and the southern 489 lagoon that covers $136.21 \mathrm{Km}^{2}(5.4 \%)$ feeds on the runoff of $16.5 \%$, which in part explains the 490 fact that the north lagoon has perennial water and the southern lagoon has a rather intermittent 491 behavior.

492

493

494

495

496

497

498

499

500

501

502

503

504

505

506

507

508

509

510
Figure 7. Map of aquifer overexploitation by micro-basins Source: Self-made

\section{$\underline{\text { Analysis of scenarios }}$}

$\underline{\text { Scenario zero }}$

It arises from the hydrological balance made only with the natural conditions of rainfall and runoff without taking into consideration the infrastructure and giving zero value to human uses, this allows having an overview of the natural condition of the micro-basins in order to locate the criteria of analysis. The results obtained in the indicators for this scenario are presented in Table 7.

\section{$\underline{\text { Status quo scenario }}$}

The status quo scenario (Table 8) corresponds to the integrated hydrological balance of the current conditions of the basin through the analysis of the water resource uses reported by the National Water Commission (CONAGUA) in the Public Registry of Water Rights.

From this analysis, it can be summarized that the basin currently has an groundwater use of $318 \%$ compared to the annual volume infiltrated to the aquifer; hence its condition of overexploitation, the micro-basins that currently have the greatest pressure on the aquifer are: Tejamen (419\%), El Gato (721\%), Tinajuelas (478\%), Las Jarillas (356\%), El Padrón (412\%) and El Colorado (303\%).

\section{$\underline{\text { Low scenario }}$}

The results of the low scenario are presented in Table 9, under the schemes of normative regulation of groundwater extraction for agricultural use mainly, low and medium technification in irrigation 
511 systems. Proposing a reduction order of $20 \%$ of the losses and waste in these activities, particularly 512 those related to underground extraction.

513 The response of the basin in this scenario is an exploitation of the aquifer in $258 \%$ compared to 514 the recharge capacity, where the greatest impact is produced in the micro-watersheds: Tejamen 515 (349\%), El Gato (699\%), Tinjuelas (398\%), Las Jarillas (295\%), Padlock (337\%) and Colorado 516 (248\%), where there is a considerable decrease in the exploitation of the aquifer.

\section{$517 \underline{\text { Medium scenario }}$}

518 It was carried out under a $65 \%$ extraction of the current annual volume concessioned. The response 519 of the basin in terms of groundwater is $210 \%$ exploitation of the recharge capacity of the aquifer. 520 Under this criterion, the exploitation by micro-basins is as follows: Tejamen has an underground 521 exploitation of $292 \%$, El Gato shows an extraction of 502\%, Tinajuelas explodes in 333\%, Las 522 Jarillas presents an underground concession of $246 \%$, El Candado exploits $278 \%$ and for the 523 Colorado the groundwater resource is submitted to $205 \%$, all percentages are in relation to the 524 recharge capacity of the aquifer (Table 10).

525 Ideal scenario

526 It departs from the integrated hydrological balance where the reduction of uses is sought until 527 achieving a balance between production and use of water. This scenario allows visualizing the 528 conditions that would lead to sustainability in order to evaluate its viability, in which the 529 extractions are equal to the infiltrations of the basin (Table 11).

530 Viability of scenarios

531 Figure 8 shows the impact of the proposals of this investigation where it is observed that the viable 532 scenario allows to reduce the pressure in the aquifer going from $318 \%$ of extraction to $258 \%$ if the 533 technification of irrigation and good practices are adopted, reducing the current extraction to $20 \%$, 534 which is not economically and socially feasible.

535 Effects on the potential social and economic development of the sub-basin

536 Analyzing the human activities that take advantage of the water in the basin could be reflected in 537 the balances of surface and groundwater. It can be deduced that the micro-basins of the north area 538 have small volumes of surface availability that are not very significant. The micro-basins of the 539 south zone due to their small surface area, the dominance of temperate semi-dry climate and the 540 strong relation of the area used for agriculture present deficits in all of them.

541 In contrast, the revision of the volumes of groundwater reflects an overexploitation of the aquifer 542 in relation to recharge ranging from $116 \%$ to $738 \%$ in 10 of the 13 micro-basins.

543 In general, the high evaporation in the basin, a low average rainfall, and consequently a limited 544 recharge of the aquifer also reduced by the high presence of alluvial soils in the lower part of the 545 basin. Added to the conditions of the endorheic basin for not being connected to the rest of the 546 territory, it generates an isolated space characterized by a fragile condition for the sustainability of 547 human activities, considering the great agricultural and livestock vocation of the region where 
548 these activities are also based on the coexistence of cultures Mennonite and Mexican with deep549 rooted traditions on how to take advantage of intensive natural resources.

550 This combination of cultural practices and limited availability both on the surface and in the aquifer 551 could be understood as an intense pressure on the water resource, this generates a condition of

552 fragility to the sustainability of production systems based on water consumption (Figure 8).

Figure 8. Comparison of extraction reduction scenarios against overexploitation of the aquifer Source: Own elaboration

555

556

557 558
Table 5. Results of the balance surface waters of the micro-basins of the Laguna de Santiaguillo Source: own elaboration using NOM-011-CONAGUA-2015

Table 6. Results of the analysis of groundwater availability by micro-basin in the aquifer in Laguna de Santiaguillo

Table 7. Availability indicators in response to the zero scenario

Table 8 . Availability indicators in response to the status quo scenario

Table 9. Availability indicators in response to the low scenario

Table 10. Availability indicators in response to the medium scenario

Table 11. Availability indicators in response to the ideal scenario

\section{DISCUSSION}

The high pressures on water resources have caused a great number of problems of a political, economic, social and environmental nature (Sernet et al, 2016). Therefore, it is very important to carry out actions to ensure the sustainability of the aquifer and the society that lives in the Laguna de Santiaguillo watershed.

The physiographic and socioeconomic conditions of the region are extremely important to know the degree of vulnerability of the aquifer. There are political decisions that generate important economic spillovers, but at a high environmental cost; an example of this is what happened in the Disi aquifer in Jordan.

Towards the year of 1984, the Jordanian government allowed the establishment of four companies producing wheat that later were dedicated to the extensive agriculture of fruits and vegetables, taking the aquifer to an irreparable overexploitation. (Salameh, Alraggad, Tarawneh, 2013).

The endorreicity of the Laguna de Santiaguillo basin, its small size, the regulatory vacuum concerning the protection of this type of aquifers in particular and the agriculture that takes place within it are factors that accentuate the vulnerability of the overexploited aquifer. Currently the aquifer is over-concessioned, as a result of poor resource management.

This places agriculture as one of the vital human activities for development that generate greater water stress.

Peer) reviewing PDF | (2018:08:30469:2:2:NEW 14 Mar 2019) 
582 Water quality in an overexploited aquifer is worse than a well-maintained aquifer. A study 583 developed by Bicalho et al. concludes that greater volumes of water extraction and shorter times 584 characterize intensive extraction in aquifers. The mobilization of the deepest water levels increases 585 the mineralization of water while karstification is greater in an overexploited aquifer than in one 586 that is not (Bicalho et al, 2011).

587 It is quite relevant to note the need for studies that reveal the quality of water in the region since, 588 due to the exploitation of the aquifer, the extracted water presents a greater presence of salts and 589 minerals. In the case of the Laguna de Santiaguillo watershed, it is imperative to carry out the 590 construction of drainages associated with the tracing of the furrows in contour lines.

591 Some of the proposals mentioned by Palacios and Escobar are applicable for the Santiaguillo 592 aquifer, some of which are the formation of a technical committee for groundwater that is 593 responsible for the management of the aquifer, the artificial recharge of the aquifer and fostering 594 the collection and use of rainwater for domestic and backyard consumption (Palacios and Escobar, 595 2016).

596 The possibility is to guide the technification of irrigation, the control of the livestock population 597 within the basin and the conservation of the vegetation cover of the recharge areas, limiting the 598 expansion of the area devoted to agriculture, the productive conversion of high-yield crops 599 consumption, particularly forages.

600 However, even if this was possible, it is necessary to consider that the returns of the underground 601 extractions sustain with their contributions the volume of water in the wetland that now has a 602 RAMSAR classification. Therefore, it is necessary to carefully review the implications of such an 603 action as ideal as it may seem.

604 The balance sheets of this analysis have been made with the official information of the Public 605 Registry of Water Rights of the National Water Commission, in the absence of reliable information 606 from the underground extractions measured. It is not possible to affirm beyond the hypothesis of 607 a condition of physical overexploitation.

608 According to the CONAGUA in its report "Update of the average annual availability of 609 groundwater aquifer (1001) valley of Santiaguillo". The availability of groundwater in the 610 aquifer of Santiaguillo is obtained by subtracting from the volume of total annual recharge, the 611 value of the natural discharge committed and the volume of groundwater concessioned and 612 registered in the REPDA. $-39,351,828=25,900,000-10,393,000-54,858,828$; This indicates 613 that there is no available volume for new concessions in the hydrogeological unit called Valle de 614 Santiaguillo aquifer, in the State of Durango.

615 However, throughout this study it is demonstrated that the problem is even more serious than what 616 was proposed by the CONAGUA. Since according to the balance established in this work it was 617 demonstrated that the availability of groundwater is - 111,950,689.49=30,023,188.87 $61814,638,517.10-127,335,361.27$, this given that the conagua does not take into account all 619 concessions with title and those of folio 8 or national registration ballot 
620 Brief explanation of Figure 7. The status quo represents the current state of the aquifer, which

621

622

623

624

625

626

627

628

629

630

631

632

633

634

635

636

637

638

639

640

641

642

643

644

645

646

647

648

649

650

651

652

653

654

655

656

657 reveals an over-concession of $318 \%$. If we decrease the allowed extraction by $20 \%$, we would be talking about a low reduction of extraction achievable with changes in the cultural practices and basic technifications as well as the reduction of the number of wells through the expiration of rights, even so the extraction would be of $258 \%$, which still places it in a large overexploitation.

Decreasing the extraction concession by $35 \%$ is considered an average reduction, which implies a technification of greater scope particularly in irrigation techniques such as the use of central, or lateral pivot systems, sprinkler irrigation, extended use of belt and multi-damper, this implies an investment in all the uses and even the aquifer would be overexploited by $212 \%$.

The $70 \%$ decrease in recorded extraction is actually a high reduction of extraction which implies the advanced technification of irrigation systems such as micro-sprinkling, drip systems, deep cultural change and changes in crops, which requires a high investment that would necessarily force a government subsidy.

The sub-basins and dams: Guatimape, Tejamen Dam, Tejamen, El Gato, Tinajuelas, Dr. Castillo del Valle Dam, Las Jarillas, El Trébol, Torunos, La Redonda Dam and El Candado are in balance and feed the northern lagon that has the peculiarity of being a perennial body. On the other hand, the sub-basins Ojo de Lobo, Tinaja, Los monos, El Colorado and Viborillas feed the southern lagoon which is most dry most of the time (Table 5).

In contrast to the analysis of surface water is the analysis of availability of groundwater (Table 6), the column of infiltration represents the estimated infiltration by rain and it is the most important; however, it is affected by some human activities on the surface such as: agricultural activities and changes in vegetation cover.

The second column presents the returns directly influenced by surface irrigation, only two microbasins present this type of infiltration: Guatimape and Tejamen, both belonging to the North zone. The third column expresses the horizontal movements in the aquifer, that is to say, the interaction of water that is found in the subsoil and that generates a dynamic that is affected to a greater or lesser extent by the extractions.

The column of evapotranspiration alludes to the exchange that exists between the subsoil and the atmosphere, the micro-watershed with greater affection by this factor is that of Tinajuelas.

The average annual recharge columns and the natural discharge committed reflect the behavior of the system in a natural way; again the micro-basins of Guatimape and Tejamen turn out to have the highest values in terms of aquifer recharge while having the highest values of natural discharge committed.

The column of underground volume concessioned indicates the volume that is concessioned to the different uses, agricultural, industrial, etc. In regard to underground availability per micro-basin, it is observed that all the micro-basins are in deficit. Only three of them (Ojo de Lobo, Los Monos and Viborillas) are in positive numbers; it is worth mentioning that the volume concessioned in the latter is minimal

Peer) reviewing PDF | (2018:08:30469:2:2:NEW 14 Mar 2019) 
658 Finally, the exploitation/ recharge column indicates the relationship between extractions and 659 recharges in percentage. In this case, it is important to note the percentage of $783 \%$ in the micro660 basin of El Gato, where the pressure exerted on it is such that the recharge capacity is substantially 661 surpassed (Table 6 and Figure 7).

662 It is convenient not to lose sight of the fact that it is a single aquifer, the segmentation obeys to the 663 superficial distribution in micro-watersheds to describe in a regionalized way the pressure that 664 human activities exert on it.

665 From the comparison of both tables, it is possible to observe that it depends on most of the socio666 economic activities of the groundwater, which in terms of agricultural use is 5 times greater than 667 what the existing surface water infrastructure can provide.

668 It could be thought that one solution is to promote the use of surface water, but technically this is 669 not possible in all cases, due to the distribution of runoff and the regionalization of socioeconomic 670 activities. Based on the above, the degree of overexploitation of the underground aquifer is evident, 671 which shows the vulnerability of the system to sustain itself for a long time.

672 All the rules, issues and procedures involve peasants, sellers and groups with agriculture interests 673 as well as politicians, legislators and judges. They control the access to the means of production 674 and establish the economic and social interests in relation to the natural, technological and human 675 resources. Moreyra et al mention the relevance of legislation and the entities involved in food 676 production. It is worth mentioning the role of the market since it incentives environmental 677 overexploitation in general to satisfy demand, which most of the time fails to arise from necessity 678 but from overproduction (Moreyra et al, 2012).

679 In Santiaguillo Basin, there is little efficiency both by the regulator and by society. This apathy 680 may be due to various aspects including the small size of the aquifer as well as the lack of 681 knowledge on the part of some residents regarding the current conditions of overexploitation found 682 in the aquifer. All this contributes to an increase in the vulnerability of the aquifer.

683 It is, therefore, necessary to determine with sufficient precision the actual volume extracted by 684 direct measurements and monitoring of the volumes delivered by the underground wells, with the 685 purpose of knowing the dynamics and the affectation to specify the degree of vulnerability. With 686 the information generated from this study there is sufficient evidence to place focus on the basin.

687 In this study, it is evident that there is no way to solve the overexploitation of the aquifer of the 688 Laguna de Santiaguillo basin, but if actions are taken it is possible to mitigate the impacts on the 689 aquifer.

690 To achieve a good mitigation of the impacts caused to the aquifer, actions are visualized in three 691 sectors: technological actions, cultural practices and normative aspects.

692 Technological actions: change the way in which the risks are applied, it is necessary to establish 693 efficient water use system such as drip irrigation, high efficiency systems, sprinkler systems and 694 line, currently the irrigation that is carried out is by flood. 
695 Cultural practices: that is, the way in which the land is worked, level curves, construction of 696 drainage networks.

697 Regulatory aspects: local agreements that can be built in the COTAS (in Spanish it stands for: 698 Underground Water Technical Committee) (http://www.cocurs.mx/cotas.php, consultation: 699 June/2018), this entity allows to group users working for the improvement and establishment of

700

701

702

703

704

705

706

707

708

709

710

711

712

713

714

715

716

717

718

719

720

721

722

723

724

725

726

727

728

729

730

731

732 own regulations. Self-regulations or regulations from an external entity are needed.

\section{CONCLUSIONS}

The population of the Santiaguillo Basin is vulnerable to the exploitation of the aquifer, since all micro-basins remain at the level of water availability per day, it is important to emphasize that agriculture is the economic activity supported by the population and, at the same time, it consumes more than $90 \%$ of the water available in the aquifer. Even considering a scenario where extraction is drastically reduced, the level of water availability for development is catastrophically low, which shows that the remedial actions are unsustainable given the condition of the aquifer. Therefore, it would only be possible to propose mitigation measures to sustain the aquifer and its population for a certain period of time.

Activities such as extended forage production may collapse, thereby threatening farming in the basin.

The micro-basin that has the greatest exploitation is the so-called "El Gato" where there are wellestablished Mennonite communities, in which the fact of an excessive drilling of well stands out since these communities are immune usually to the application of Mexican regulations on prudent distance of the perforation between well and well. It is extremely important that the regulations permeate all inhabitants of the region, since the actions of a few impact the entire aquifer and affect all the inhabitants of the basin.

An exacerbation of the condition of overexploitation of the aquifer is foreseen, so the measures of control and reduction of the underground water volumes concessioned would have to be a policy established in particular for this area.

Maximizing the use of surface water could contribute, but only very marginally, to reducing overexploitation of the aquifer.

Some of the possible mitigation proposals are: the technification of irrigation, the control of the livestock population within the basin and the conservation of the vegetation cover of the recharge areas, limiting the expansion of the area dedicated to agriculture, the productive conversion of high-consumption crops, particularly forages.

It is necessary to generate governance processes in greater depth, so it is necessary to reach the construction of local agreements between water users to detonate sustainability processes.

However, even if this was possible, it is necessary to consider that the returns of the underground extractions sustain with their contributions the volume of water in the wetland that now has a RAMSAR classification, so it is necessary to carefully review the implications of such an action as ideal as it may seem. 
733 It is therefore necessary to determine with sufficient precision the actual volume extracted by direct

734

735

736

737

738

739

740

741

742

743

744

745

746

747

748

749

750

751

752

753

754

755

756

757

758

759

760

761

762

763

764

765

766

767

768

measurements and monitoring of the volumes delivered by the underground wells.

It is considered that the results of this research project are sufficient to warn that in this small endorheic sub-basin the productive activities and quality of life are at risk given the vulnerability related to water availability.

\section{REFERENCES}

Altieri M. (1999). Biotecnología agrícola: mitos, riesgos ambientales y alternativas. Berkeley: Universidad de California.

Cantú-Martínez, P. C. (2012). El conflicto ambiental del agua en los albores del siglo XXI. Ciencia UANL, 15(59),20-29.

Campos-Vargas M, Toscana-Aparicio A, Campos-Alanís J (2014). Riesgos socionaturales: vulnerabilidad socioeconómica, justicia ambiental y justicia espacial. Revista colombiana de Geografía. Vol 24. No. 2. Bogotá Colombia. Pp 53-69.

CONAGUA. (April 20, 2015). Actualización de la disponibilidad media anual de agua en el acuifero Valle de Santiaguillo (1001), Estado de Durango. Comisión Nacional del Agua, Subdirección General Técnica. México, D.F.: Diario Oficial de la Federación. Retrieved on March 3, 2018,from https:/www.gob.mx/cms/uploads/attachment/file/103632/DR_1001.pdf

CONAGUA. (2011). Análisis de Alternativas de Manejo de la Demanda y la Disponibilidad del Agua de la Cuenca Alta del Rio Mezquital, Estado de Durango. Comisión Nacional del Agua, Durango, México.

CONANP. (2 de Febrero de 2012). Humedales de México, Sitios RAMSAR. Obtenido de Comisión Nacional de Areas Naturales Protegidas: http://ramsar.conanp.gob.mx/docs/sitios/FIR_RAMSAR/Ingresos2012/Durango/2012\%20Mexic o\%20Laguna\%20Santiaguillo\%20RIS.pdf

COTAS (in Spanish it stands for Comité Técnico de Aguas Subterráneas, which may be translated to English as: Underground Water Technical Committee) (http://www.cocurs.mx/cotas.php, Retrieved on: June/2018)

Custodio, E. (2002). Aquifer overexploitation: what does it mean? Springer- Verlag, Hydrogeology Journal 10, 254-277

Domínguez Alonso, A. P. (2011). La prestación de los servicios de abastecimiento de agua potable y saneamiento por parte de los municipios en México. Multidisciplina, (9).

Comisión Nacional del Agua (2017). Estadísticas del Agua en México. Secretaría de Medio Ambiente y Recursos Naturales. pp 291

Fernández, Cirelli, A. Y. P., \& du Mortier, C. (2005). Evaluación de la condición del agua para consumo humano en Latinoamérica. Tecnologías solares para la desinfección y descontaminación del agua. Solar Safe Water, 11-26.

Peer) reviewing PDF | (2018:08:30469:2:2:NEW 14 Mar 2019) 
769 Fondo para la comunicación y la Educación Ambiental, Centro Mexicano de Derecho Ambiental 770 y Presencia Ciudadana Mexicana (2006). El Agua en México: lo que todas y todos debemos saber.

771 México: FEA- Cemda-PCM.

772 INEGI. (2005). Guia para la Interpretación de Cartografía Climatológica. Instituto Nacional de

773 Estadistica, Geografía e Informatica. Retrieved from

$774 \mathrm{http} / /$ internet.contenidos.inegi.org.mx/contenidos/productos/prod_serv/contenidos/espanol/bvine

775 gi/productos/historicos/1329/702825231781/702825231781_1.pdf

776 INEGI. (Diciembre de 2011). Censos de Población y VIvienda. Instituto Nacional de Estadística,

777 Geografía e Informática, México, D.F. Retrieved from http://www.censo2010.org.mx

778 INEGI (2018). Antares. Electronic consultation November 7, 2018. 779 http://antares.inegi.org.mx/analisis/red_hidro/siatl/\#

780 Information on the weather regulations of the National Meteorological Service. $781 \mathrm{http} / / / \mathrm{smn}$. cna.gob.mx/es/informacion-climatologica-ver-estado?estado=dgo. Retrieved on 782 November 5, 2018

783 Khezzani, B., Bouchemal, S. (2018). Variations in groundwater levels and quality due to 784 agricultura over-exploitation in an arid environment: The phreatic aquifer of the souf oasis (algrian 785 Sahara). Environmental Earth Sciences, 77(4), 1-18. Doi: 10.1007/s 12665-018-7329-2.

786 Martínez R. (2009). Agricultura, alimentación y salud: debate crítico. Perspectivas en Nutrición 787 humana. Universidad de Antioquía. Medellín. Colombia vol. 11. No.1 pages 73-90 ISSN: 0124$788 \quad 4108$

789 Molina Garza, R. (2013). Centro de Geociencias Universidad Nacional Autónoma de México. 790 Recuperado el 16 de 06 de 2013, de Abanicos Aluviales, Tema del curso: Ambientes y procesos 791 sedimentarios (Posgrado en ciencias de la Tierra): $792 \mathrm{http} / / / \mathrm{www}$. geociencias.unam.mx/ rmolina/documents/alluvialfanslecture.pdf

793 Moreyra A, Puricelli M, Mercader A, Rey M. (2012). El Acceso al agua de los agricultores 794 familiares de la región pampeana: un análisis multidimensional. Mundo Agrario 12(24), ISSN $795 \quad 1515-5994$.

796 Nieto-Samaniego, Á. F., Barajas-Gea, C. I., Gómez-González, J. M., Rojas, A., Alaniz-Álvarez, 797 S. A., \& Xu, S. (2012). Geology, structural evolution (Eocene to recent) and seismic events in the 798 Santiaguillo graben, Durango, México. Revista mexicana de ciencias geológicas, 29(1), 115-130. 799 Retrieved on March 3, for 800 http://www.scielo.org.mx/scielo.php?script=sci_arttext\&pid=S1026-

$80187742012000100008 \& \operatorname{lng}=$ es\&tlng=en

802 Norma Oficial Mexicana NOM-011- CONAGUA- 2015, Conservación del recurso agua que 803 establece las especificaciones y el método para determinar la disponibilidad media anual de las 804 aguas nacionales. Diario Oficial de la Federeación.27 de marzo del 2015. Electronic 805 Consultation: http://www.dof.gob.mx/nota_detalle.php?codigo $=5387027 \&$ fecha $=27 / 03 / 2015$ 
806 Palacios-Vélez O, Escobar- Villagrán B (2016). La sustentabilidad de la agricultura de riego ante 807 la sobreexplotación de acuiferos. Tecnología y ciencias del Agua, Vol VII, núm. 2, pp 5-16.

808 Reforma, México D.F. México, Cervantes (2015). Advierten por deterioro en los mantos acuíferos. 809 Informe Académico, Accessed 5 July 2018, MLA 8 . edición 810 http://link.galegroup.com/apps/doc/A434322141/IFME?u=pu\&sid=IFME\&xid=e05e5c48

811 Registro público de derechos del agua REPDA. Electronic consult: 812 https://app.conagua.gob.mx/Repda.aspx consult on november 2018

813 Salameh E, Alraggad M, Tarawneh A. (2013). Disi water use for irrigation- a false decisión and 814 its consequences. Clean- soil, Air, Water 2014, 42 (12), 1681-1686. DOI: $81510.1002 /$ clen.201300647.

816 Senet-Aparicio J, Pérez- Sánchez J, Bielsa-Artero A. (2016) Evaluación de la sostenibilidad de 817 cuencas mediterraneas semiáridas. Caso de estudio: cuenca del Segura, España. Tecnología y 818 ciencias del Agua, vol VII, núm. 2,pp 67-84.

819 World Bank. Banco Internacional de Reconstrucción y Fomento/ Banco Mundial. (2002). 820 Protección de la Calidad del Agua subterránea, guía para empresas de agua, autoridades 821 municipales y agencias ambientales. Ediciones Mundi- Prensa Libros, S.A. ISBN:84-8476-146-0. 


\section{Table $\mathbf{1}$ (on next page)}

Types of climate and its extension in the sub-basin

Table elaborated with vector information from INEGI (for its acronym in Spanish, National Institute of Statistics and Geography) 
1 Table 1. Types of climate and its extension in the sub-basin

\begin{tabular}{lcc}
\hline Climate & Hectares & Percentage \\
\hline BS1kw(w) & $180,668.15$ & 71.07 \\
\hline C(E)(w1) & $14,206.50$ & 5.59 \\
\hline C(E)(w2) & $14,601.78$ & 5.74 \\
\hline C(w0) & $26,044.58$ & 10.25 \\
\hline C(w1) & $18,695.20$ & 7.35 \\
\hline
\end{tabular}

2 Source: own elaboration with vector information of INEGI (For its acronym in Spanish, National 3 Institute of Statistics and Geography)

4 
Table 2 (on next page)

Soil surface by texture of the sub-basin

Table elaborated with vector data from INEGI 
1

2

Table 2. Soil surface by texture of the sub-basin

\begin{tabular}{lcc}
\hline Texture & Hectares & Percentage \\
\hline Medium & $141,793.72$ & $55.78 \%$ \\
\hline Fine & $77,436.36$ & $30.46 \%$ \\
\hline Gross & $22,909.04$ & $9.01 \%$ \\
\hline N/A Water body & $12,077.11$ & $4.75 \%$ \\
\hline
\end{tabular}

3

Source: Own elaboration with vector data of INEGI

4 


\section{Table 3(on next page)}

Levels of water availability

Source: Shiklomanov, Igor, World Water resources at the beginning of the 21st century, PHIUNESCO,2002 
1

2

Tabla 3. Levels of water availability

\begin{tabular}{|c|c|}
\hline $\begin{array}{c}\text { Availability of water in thousands } \mathbf{~ m}^{\mathbf{3}} \text { / } \\
\text { hab / year }\end{array}$ & Water availability levels \\
\hline$<1$ & Catastrophically low \\
\hline $1.1-2.0$ & Very low \\
\hline $2.1-5.0$ & low \\
\hline $5.1-10$ & medium \\
\hline $10.1-20$ & high \\
\hline$>20$ & Very high \\
\hline
\end{tabular}

3 Fuente: Shiklomanov, Igor, World Water resources at the beginning of the 21st century, 4 PHIUNESCO,2002

5

6 


\section{Table 4(on next page)}

Number and volume of the underground sources granted

Table elaborated with information from the Public Register of Water Rights, of the National Commission of Water. 
Table 4. Number and volume of the underground sources granted

\begin{tabular}{lrr}
\hline Use & $\begin{array}{r}\text { Number of } \\
\text { wells }\end{array}$ & $\begin{array}{r}\text { Concession volume } \\
\text { Thousands of } \mathrm{m}^{3}\end{array}$ \\
\hline Agricultural & 1329 & $5,233.70$ \\
Livestock & 464 & 360.36 \\
Domestic & 49 & 20.76 \\
Urban public & 91 & $1,959.75$ \\
Multiple & 26 & 607.86 \\
Different uses & 2 & 19.88 \\
Industrial & 5 & 6.87
\end{tabular}

2 Source: Own elaboration with information of the Public Register of water rights, of the National 3 Commission of water.

4 


\section{Table 5 (on next page)}

Results of the balance surface waters of the micro-basins of the Laguna de Santiaguillo

Results of the balance elaboration using the method given by the NOM-011-CONAGUA-2015 
1 Table 5. Results of the balance surface waters of the micro-basins of the Laguna de Santiaguillo Source: own elaboration using NOM-011-CONAGUA-2015

$\begin{array}{llllll}\begin{array}{l}\text { Name of the } \\ \text { Hydrological }\end{array} & \begin{array}{l}\text { Cp.- Annual } \\ \text { average volume of } \\ \text { nab-basin }\end{array} & \begin{array}{l}\text { Ab.- } \\ \text { Average annual } \\ \text { volume of runoff } \\ \text { from the basin } \\ \text { downstream }\end{array} & \begin{array}{l}\text { Rxy.- Current } \\ \text { annual committed } \\ \text { downstream }\end{array} & \begin{array}{l}\text { Ab- } \\ \text { Rxy }\end{array} & \begin{array}{l}\text { D.- Average } \\ \text { annual } \\ \text { availability of } \\ \text { Surface water in } \\ \text { the hydrological } \\ \text { basin }\end{array}\end{array}$

\begin{tabular}{lllllll}
\hline Guatimape & 18.66 & 18.24 & 10.72 & 7.52 & 7.52 & -4.51 \\
\hline P Tejamen & 3.75 & 3.61 & 7.24 & -3.63 & 5.95 & BALANCE \\
\hline Tejamen & 17.46 & 12.58 & 7.24 & 5.15 & 9.15 & BALANCE \\
\hline El Gato & 14.81 & 14.72 & 5.57 & 15.61 & 15.61 & BALANCE \\
\hline Tinajuelas & 37.35 & 36.81 & 21.20 & 0.40 & 0.31 & BALANCE
\end{tabular}

Presa Dr.

Castillo del

Valle

\begin{tabular}{|c|c|c|c|c|c|c|}
\hline Las Jarillas & 4.53 & 4.52 & 2.32 & 2.20 & 2.61 & BALANCE \\
\hline El Trébol & 2.01 & 2.00 & 1.23 & 0.76 & 0.76 & BALANCE \\
\hline Torunos & 5.15 & 5.08 & 3.67 & 1.42 & 1.42 & DEFICIT \\
\hline $\begin{array}{l}\text { Presa La } \\
\text { Redonda }\end{array}$ & 3.54 & 3.33 & 0.17 & 3.16 & 2.95 & ABUNDANCE \\
\hline El Candado & 9.72 & 9.54 & 3.65 & 5.90 & 9.23 & AVAILABILITY \\
\hline Laguna Norte & 44.18 & 11.36 & - & 11.36 & 102.13 & - \\
\hline Ojo de Lobo & 2.68 & 2.66 & 2.67 & -0.01 & -0.01 & DEFICIT \\
\hline Tinaja & 5.26 & 4.87 & 6.32 & -1.45 & -1.45 & DEFICIT \\
\hline Los Monos & 2.12 & 2.06 & 2.24 & -0.18 & -0.18 & DEFICIT \\
\hline El colorado & 6.79 & 6.42 & 8.49 & -2.07 & -2.07 & DEFICIT \\
\hline Viborillas & 4.86 & 4.83 & 4.47 & 0.36 & 0.36 & DEFICIT \\
\hline Laguna Sur & 72.64 & 48.73 & - & 48.73 & 93.47 & - \\
\hline
\end{tabular}

3 
Table 6(on next page)

Results of the analysis of groundwater availability by micro-basin in the aquifer in Laguna de Santiaguillo

Analysis of groundwater availability by micro-basin 
2 Table 6. Results of the analysis of groundwater availability by micro-basin in the aquifer in Laguna de Santiaguillo

\begin{tabular}{|c|c|c|c|c|c|c|c|c|c|}
\hline \multirow[t]{2}{*}{ Micro-basin } & Rain Infiltration & $\begin{array}{l}\text { Infiltration for } \\
\text { returns }\end{array}$ & Horizontal entry & $\begin{array}{l}\text { Evapo- } \\
\text { transpiration }\end{array}$ & \multirow[t]{2}{*}{$\begin{array}{l}\text { Total Annual } \\
\text { average } \\
\text { recharge }\end{array}$} & \multirow[t]{2}{*}{$\begin{array}{l}\text { Natural } \\
\text { discharge } \\
\text { committed }\end{array}$} & \multirow{2}{*}{$\begin{array}{l}\text { Subscribed } \\
\text { underground } \\
\text { volume } \\
\text { B }\end{array}$} & \multirow{2}{*}{$\begin{array}{l}\text { Underground } \\
\text { availability } \\
\text { Dm }\end{array}$} & \multirow[t]{2}{*}{$\begin{array}{l}\text { exploitation / } \\
\text { recharge }\end{array}$} \\
\hline & Ip & Ir & Eh & Evt & & & & & \\
\hline Guatimape & 0.84 & 0.32 & 2.10 & 182.67 & 3.25 & 182.67 & 4.55 & -183.97 & $140 \%$ \\
\hline Tejamen & 1.27 & 0.90 & 1.01 & 115.46 & 3.17 & 115.46 & 12.38 & -124.67 & $390 \%$ \\
\hline El Gato & 1.09 & - & 0.41 & 98.52 & 1.49 & 98.52 & 11.68 & -108.71 & $783 \%$ \\
\hline Tinajuelas & 5.37 & - & 2.04 & 314.06 & 7.41 & 314.06 & 40.75 & -347.41 & $550 \%$ \\
\hline Las Jarillas & 0.77 & - & 0.31 & 36.01 & 1.08 & 36.01 & 6.57 & -41.50 & $608 \%$ \\
\hline El Trébol & 0.50 & - & 0.15 & 19.88 & 0.65 & 19.88 & 0.75 & -19.98 & $116 \%$ \\
\hline Torunos & 1.09 & - & 0.41 & 49.90 & 1.51 & 49.90 & 5.55 & -53.94 & $369 \%$ \\
\hline El Candado & 0.40 & - & 0.48 & 63.77 & 0.88 & 63.77 & 4.23 & -67.12 & $478 \%$ \\
\hline Ojo de Lobo & 0.26 & - & 0.18 & 0.24 & 0.44 & 0.24 & 0.00 & 0.20 & $0 \%$ \\
\hline Tinaja & 0.56 & - & 0.30 & 0.52 & 0.86 & 0.52 & 1.64 & -1.30 & $191 \%$ \\
\hline Los Monos & 0.21 & - & 0.18 & 0.19 & 0.39 & 0.19 & 0.02 & 0.18 & $6 \%$ \\
\hline El Colorado & 1.21 & - & 0.43 & 1.12 & 1.64 & 1.12 & 6.75 & -6.23 & $412 \%$ \\
\hline Viborillas & 0.32 & - & 0.14 & 0.30 & 0.46 & 0.30 & 0.03 & 0.14 & $6 \%$ \\
\hline
\end{tabular}

3 
Table 7 (on next page)

Availability indicators in response to the zero scenario

Source: Authors' own elaboration using Shiklomanov values 
1 Table 7. Availability indicators in response to the zero scenario

\begin{tabular}{|c|c|c|c|c|c|c|c|c|}
\hline Micro-basin & $\begin{array}{l}\text { Natural Surface } \\
\text { availability per } \\
\text { capita } \mathrm{m}^{3}\end{array}$ & $\begin{array}{c}\text { Level of } \\
\text { availability per } \\
\text { capita natural } \\
\text { water } \\
\text { (Shiklomanov, } \\
\text { 2002) }\end{array}$ & $\begin{array}{l}\text { Availability for } \\
\text { development } \mathrm{m}^{3}\end{array}$ & $\begin{array}{l}\text { Level of availability } \\
\text { for development } \\
\text { (Shiklomanov, 2002) }\end{array}$ & $\begin{array}{c}\text { Natural } \\
\text { availability } \\
\text { underground per } \\
\text { capita } \mathrm{m}^{3}\end{array}$ & $\begin{array}{l}\text { Level of availability } \\
\text { per capita natural water } \\
\text { (Shiklomanov, 2002) }\end{array}$ & $\begin{array}{l}\text { Availability for } \\
\text { development } \\
\mathrm{m}^{3}\end{array}$ & $\begin{array}{l}\text { Level of availability per } \\
\text { capita natural water } \\
\text { (Shiklomanov, 2002) }\end{array}$ \\
\hline Guatimapé & $13,460.85$ & High & $7,791.03$ & Medium & $2,116.60$ & Low & $1,768.71$ & Very Low \\
\hline Tejamen & $6,075.61$ & Medium & $4,172.20$ & Low & 652.01 & Catastrophically Low & 601.62 & Catastrophically Low \\
\hline El Gato & $1,210.52$ & Very Low & 873.74 & Catastrophically Low & 121.97 & Catastrophically Low & 65.67 & Catastrophically Low \\
\hline Tinajuelas & $4,021.41$ & Low & $2,312.49$ & Low & 797.38 & Catastrophically Low & 737.78 & Catastrophically Low \\
\hline Las Jarillas & $3,014.57$ & Low & $1,949.25$ & Very Low & 647.09 & Catastrophically Low & 328.32 & Catastrophically Low \\
\hline El Trébol & $5,411.61$ & Medium & $2,974.21$ & Low & $1,736.09$ & Very Low & $1,204.08$ & Very Low \\
\hline Torunos & $5,839.21$ & Medium & $2,756.27$ & Low & $1,707.23$ & Very Low & 160.19 & Catastrophically Low \\
\hline El Candado & $14,288.59$ & High & $11,031.89$ & High & 952.73 & Catastrophically Low & 837.89 & Catastrophically Low \\
\hline Ojo de Lobo & $536,810.28$ & Very High & $205,749.29$ & Very High & $87,345.81$ & Very high & $-123,176.01$ & Catastrophically Low \\
\hline La Tinaja & $6,063.64$ & Medium & $1,169.80$ & Very Low & 992.68 & Catastrophically Low & -745.11 & Catastrophically Low \\
\hline Los Monos & $41,663.46$ & Very High & $13,562.84$ & High & $7,659.71$ & Medium & $-3,163.80$ & Catastrophically Low \\
\hline El Colorado & $3,852.35$ & Low & 704.43 & Catastrophically Low & 929.50 & Catastrophically Low & 627.87 & Catastrophically Low \\
\hline Viborillas & $41,149.90$ & Very High & $17,949.19$ & High & $3,932.24$ & Low & $-3,096.35$ & Catastrophically Low \\
\hline
\end{tabular}

2 
Table 8(on next page)

Availability indicators in response to the status quo scenario

Table made using NOM-011-CONAGUA-2015 and IMTA manual 
1 Table 8. Availability indicators in response to the status quo scenario

\begin{tabular}{|c|c|c|c|c|c|c|c|c|}
\hline Micro-basin & $\begin{array}{l}\text { Natural Surface } \\
\text { availability per } \\
\text { capita } \mathrm{m}^{3}\end{array}$ & $\begin{array}{c}\text { Level of } \\
\text { availability per } \\
\text { capita natural } \\
\text { water }\end{array}$ & $\begin{array}{l}\text { Availability for } \\
\text { development } \mathrm{m}^{3}\end{array}$ & $\begin{array}{l}\text { Level of availability } \\
\text { for development }\end{array}$ & $\begin{array}{c}\text { Natural } \\
\text { availability } \\
\text { underground per } \\
\text { capita } \mathrm{m}^{3}\end{array}$ & $\begin{array}{l}\text { Level of availability } \\
\text { per capita natural water }\end{array}$ & $\begin{array}{c}\text { Availability for } \\
\text { development } \\
\mathrm{m}^{3}\end{array}$ & $\begin{array}{l}\text { Level of availability per } \\
\text { capita natural water }\end{array}$ \\
\hline Guatimapé & $13,460.85$ & High & $7,428.39$ & Medium & $2,237.48$ & Low & 60.08 & Catastrophically Low \\
\hline Tejamen & $6,075.61$ & Medium & $2,990.30$ & Low & 826.17 & Catastrophically Low & $-2,684.85$ & Catastrophically Low \\
\hline El Gato & $1,210.52$ & Very Low & 932.75 & Catastrophically Low & 150.89 & Catastrophically Low & -992.72 & Catastrophically Low \\
\hline Tinajuelas & $4,021.41$ & Low & $2,597.11$ & Low & 989.47 & Catastrophically Low & $-3,800.38$ & Catastrophically Low \\
\hline Las Jarillas & $3,014.57$ & Low & $1,748.41$ & Very Low & 785.17 & Catastrophically Low & $-2,331.70$ & Catastrophically Low \\
\hline El Trébol & $5,411.61$ & Medium & $3,021.53$ & Low & $1,797.15$ & Very Low & $-2,990.13$ & Catastrophically Low \\
\hline Torunos & $5,839.21$ & Medium & $2,776.44$ & Low & $1,922.16$ & Very Low & $-3,960.13$ & Catastrophically Low \\
\hline El Candado & $14,288.59$ & High & $6,778.18$ & Medium & $1,115.25$ & Very Low & $-3,597.86$ & Catastrophically Low \\
\hline Ojo de Lobo & $536,810.28$ & Very High & $205,340.18$ & Very High & $87,345.81$ & Very High & $-123,362.21$ & Catastrophically Low \\
\hline La Tinaja & $6,063.64$ & Medium & $1,105.08$ & Very Low & $1,054.22$ & Very Low & $-3,228.21$ & Catastrophically Low \\
\hline Los Monos & $41,663.46$ & Very High & $13,587.91$ & High & $7,676.18$ & Medium & $-3,382.63$ & Catastrophically Low \\
\hline El Colorado & $3,852.35$ & Low & 871.35 & Catastrophically Low & $1,048.01$ & Very Low & $-2,432.57$ & Catastrophically Low \\
\hline Viborillas & $41,149.90$ & Very High & $17,802.71$ & High & $3,932.24$ & Low & $-4,464.37$ & Catastrophically Low \\
\hline
\end{tabular}

2 
Table 9 (on next page)

Availability indicators in response to the low scenario

Table elaborated using Shklomanov criteria 
Table 9. Availability indicators in response to the low scenario

\begin{tabular}{|c|c|c|c|c|c|c|c|c|}
\hline Micro-basin & $\begin{array}{l}\text { Natural Surface } \\
\text { availability per } \\
\text { capita } \mathbf{m}^{3}\end{array}$ & $\begin{array}{l}\text { Level of } \\
\text { availability per } \\
\text { capita natural } \\
\text { water }\end{array}$ & $\begin{array}{l}\text { Availability for } \\
\mathbf{m}^{3} \text { development }\end{array}$ & $\begin{array}{c}\text { Level of availability for } \\
\text { development }\end{array}$ & $\begin{array}{c}\text { Natural } \\
\text { availability } \\
\text { underground } \\
\text { per capita } \mathbf{m}^{3}\end{array}$ & $\begin{array}{l}\text { Level of availability } \\
\text { per capita natural } \\
\text { water }\end{array}$ & $\begin{array}{l}\text { Availability for } \\
\text { development } \mathbf{m}^{3}\end{array}$ & $\begin{array}{l}\text { Level of availability } \\
\text { per capita natural } \\
\text { water }\end{array}$ \\
\hline Guatimapé & $13,460.85$ & High & $7,396.70$ & Medium & $2,214.03$ & Low & 402.54 & Catastrophically Low \\
\hline Tejamen & $6,075.61$ & Medium & $2,931.51$ & Low & 794.29 & Catastrophically Low & $-2,024.61$ & Catastrophically Low \\
\hline El Gato & $1,210.52$ & Very Low & 920.26 & Catastrophically Low & 145.11 & Catastrophically Low & -781.03 & Catastrophically Low \\
\hline Tinajuelas & $4,021.41$ & Low & $2,538.73$ & Low & 951.06 & Catastrophically Low & $-2,892.74$ & Catastrophically Low \\
\hline Las Jarillas & $3,014.57$ & Low & $1,706.35$ & Very Low & 758.23 & Catastrophically Low & - 1,799.02 & Catastrophically Low \\
\hline El Trébol & $5,411.61$ & Medium & $3,004.28$ & Low & $1,784.94$ & Very Low & $-2,151.29$ & Catastrophically Low \\
\hline Torunos & $5,839.21$ & Medium & $2,719.68$ & Low & $1,879.52$ & Very Low & $-3,135.72$ & Catastrophically Low \\
\hline El Candado & $14,288.59$ & High & $6,734.41$ & Medium & $1,091.64$ & Very Low & $-2,701.81$ & Catastrophically Low \\
\hline Ojo de Lobo & $536,810.28$ & Very High & $205,340.18$ & Very High & $87,345.81$ & Very High & $-123,362.21$ & Catastrophically Low \\
\hline La Tinaja & $6,063.64$ & Medium & $1,085.84$ & Very Low & $1,042.16$ & Very Low & $-2,731.34$ & Catastrophically Low \\
\hline Los Monos & $41,663.46$ & Very High & $13,587.91$ & High & $7,676.18$ & Medium & $-3,382.63$ & Catastrophically Low \\
\hline El Colorado & $3,852.35$ & Low & 836.78 & Catastrophically Low & $1,024.31$ & Very Low & $-1,820.48$ & Catastrophically Low \\
\hline Viborillas & $41,149.90$ & Very High & $17,802.71$ & High & $3,932.24$ & Low & $-4,464.37$ & Catastrophically Low \\
\hline
\end{tabular}




\section{Table 10 (on next page)}

Availability indicators in response to the medium scenario

Table elaborated using NOM-011-CONAGUA-2015 and Shiklomanov criteria 
Table 10. Availability indicators in response to the medium scenario

\begin{tabular}{|c|c|c|c|c|c|c|c|c|}
\hline Micro-basin & $\begin{array}{l}\text { Natural Surface } \\
\text { availability per } \\
\text { capita } \mathbf{m}^{3}\end{array}$ & $\begin{array}{c}\text { Level of } \\
\text { availability per } \\
\text { capita natural } \\
\text { water }\end{array}$ & $\begin{array}{l}\text { Availability for } \\
\text { development } \mathbf{m}^{3}\end{array}$ & $\begin{array}{l}\text { Level of availability } \\
\text { for development }\end{array}$ & $\begin{array}{c}\quad \text { Natural } \\
\text { availability } \\
\text { underground } \\
\text { per capita } \mathrm{m}^{3}\end{array}$ & $\begin{array}{l}\text { Level of availability } \\
\text { per capita natural } \\
\text { water }\end{array}$ & $\begin{array}{l}\text { Availability for } \\
\text { development } \mathbf{m}^{3}\end{array}$ & $\begin{array}{l}\text { Level of availability per } \\
\text { capital natural water }\end{array}$ \\
\hline Guatimapé & $13,460.85$ & High & $7,372.93$ & Medium & $2,196.45$ & Low & 659.38 & Catastrophically Low \\
\hline Tejamen & $6,075.61$ & Medium & $2,887.43$ & Low & 770.38 & Catastrophically Low & $-1,529.43$ & Catastrophically Low \\
\hline El Gato & $1,210.52$ & Very Low & 910.89 & Catastrophically Low & 140.78 & Catastrophically Low & -622.27 & Catastrophically Low \\
\hline Tinajuelas & $4,021.41$ & Low & $2,494.95$ & Low & 922.25 & Catastrophically Low & $-2,212.02$ & Catastrophically Low \\
\hline Las Jarillas & $3,014.57$ & Low & $1,674.81$ & Very Low & 738.02 & Catastrophically Low & $-1,399.51$ & Catastrophically Low \\
\hline El Trébol & $5,411.61$ & Medium & $2,991.35$ & Low & $1,775.78$ & Very Low & $-1,522.15$ & Catastrophically Low \\
\hline Torunos & $5,839.21$ & Medium & $2,677.11$ & Low & $1,847.54$ & Very Low & $-2,517.41$ & Catastrophically Low \\
\hline El Candado & $14,288.59$ & High & $6,701.58$ & Medium & $1,073.94$ & Very Low & $-2,029.77$ & Catastrophically Low \\
\hline Ojo de Lobo & $536,810.28$ & Very High & $205,340.18$ & Very High & $87,345.81$ & Very High & $-123,362.21$ & Catastrophically Low \\
\hline La Tinaja & $6,063.64$ & Medium & $1,071.41$ & Very Low & $1,033.12$ & Very Low & $-2,358.68$ & Catastrophically Low \\
\hline Los Monos & $41,663.46$ & Very High & $13,587.91$ & High & $7,676.18$ & Medium & $-3,382.63$ & Catastrophically Low \\
\hline El Colorado & $3,852.35$ & Low & 810.84 & Catastrophically Low & $1,006.53$ & Very Low & $-1,361.41$ & Catastrophically Low \\
\hline Viborillas & $41,149.90$ & Very High & $17,802.71$ & High & $3,932.24$ & Low & $-4,464.37$ & Catastrophically Low \\
\hline
\end{tabular}

2 


\section{Table 11(on next page)}

Availability indicators in response to the ideal scenario

Table elaborated using NOM-011-CONAGUA-2015 and Shiklomanov criteria 
Table 11. Availability indicators in response to the ideal scenario

\begin{tabular}{|c|c|c|c|c|c|c|c|c|}
\hline Micro-basin & $\begin{array}{c}\text { Natural Surface } \\
\text { availability per } \\
\text { capita } \mathbf{m}^{3}\end{array}$ & $\begin{array}{l}\text { Level of } \\
\text { availability per } \\
\text { capita natural } \\
\text { water }\end{array}$ & $\begin{array}{l}\text { Availability for } \\
\text { development } \mathrm{m}^{3}\end{array}$ & $\begin{array}{l}\text { Level of availability } \\
\text { for development }\end{array}$ & $\begin{array}{c}\text { Natural } \\
\text { availability } \\
\text { underground } \\
\text { per capita } \mathbf{m}^{3}\end{array}$ & $\begin{array}{l}\text { Level of availability } \\
\text { per capita natural } \\
\text { water }\end{array}$ & $\begin{array}{l}\text { Availability for } \\
\text { development } \mathbf{m}^{3}\end{array}$ & $\begin{array}{l}\text { Level of availability } \\
\text { per capital natural } \\
\text { water }\end{array}$ \\
\hline Guatimapé & $13,460.85$ & High & $7,317.48$ & Medium & $2,155.41$ & Low & $1,258.67$ & Very Low \\
\hline Tejamen & $6,075.61$ & Medium & $2,784.56$ & Low & 714.58 & Catastrophically Low & -374.00 & Catastrophically Low \\
\hline El Gato & $1,210.52$ & Very Low & 889.04 & Catastrophically Low & 130.67 & Catastrophically Low & -251.82 & Catastrophically Low \\
\hline Tinajuelas & $4,021.41$ & Low & $2,392.80$ & Low & 855.02 & Catastrophically Low & -623.66 & Catastrophically Low \\
\hline Las Jarillas & $3,014.57$ & Low & $1,601.20$ & Very Low & 690.88 & Catastrophically Low & -467.32 & Catastrophically Low \\
\hline El Trébol & $5,411.61$ & Medium & $2,961.17$ & Low & $1,754.41$ & Very Low & -54.18 & Catastrophically Low \\
\hline Torunos & $5,839.21$ & Medium & $2,577.78$ & Low & $1,772.92$ & Very Low & $-1,074.69$ & Catastrophically Low \\
\hline El Candado & $14,288.59$ & High & $6,624.99$ & Medium & $1,032.63$ & Very Low & -461.69 & Catastrophically Low \\
\hline Ojo de Lobo & $536,810.28$ & Very High & $205,340.18$ & Very High & $87,345.81$ & Very High & $-123,362.21$ & Catastrophically Low \\
\hline La Tinaja & $6,063.64$ & Medium & $1,037.73$ & Very Low & $1,012.03$ & Very Low & $-1,489.16$ & Catastrophically Low \\
\hline Los Monos & $41,663.46$ & Very High & $13,587.91$ & High & $7,676.18$ & Medium & $-3,382.63$ & Catastrophically Low \\
\hline El Colorado & $3,852.35$ & Low & 750.34 & $\begin{array}{c}\text { Catastrophically } \\
\text { Low }\end{array}$ & 965.05 & Catastrophically Low & -290.26 & Catastrophically Low \\
\hline Viborillas & $41,149.90$ & Very High & $17,802.71$ & High & $3,932.24$ & Low & $-4,464.37$ & Catastrophically Low \\
\hline
\end{tabular}


Figure 1

\section{Topoform system map}

\section{Map using INEGI data}

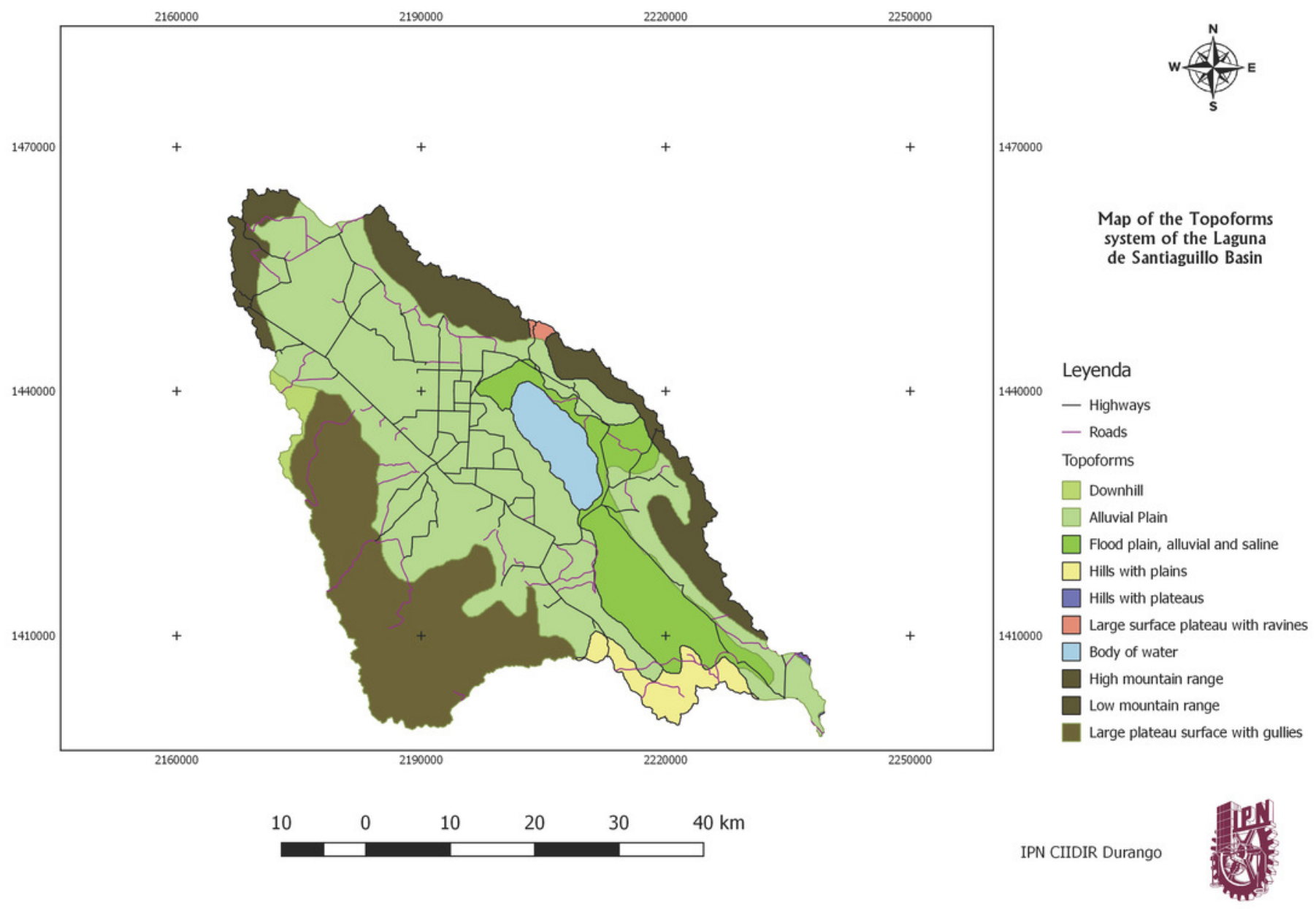


Figure 2

Hydrograhic Map Of Laguna de Santiaguillo Basin

Map made with vector information of INEGI

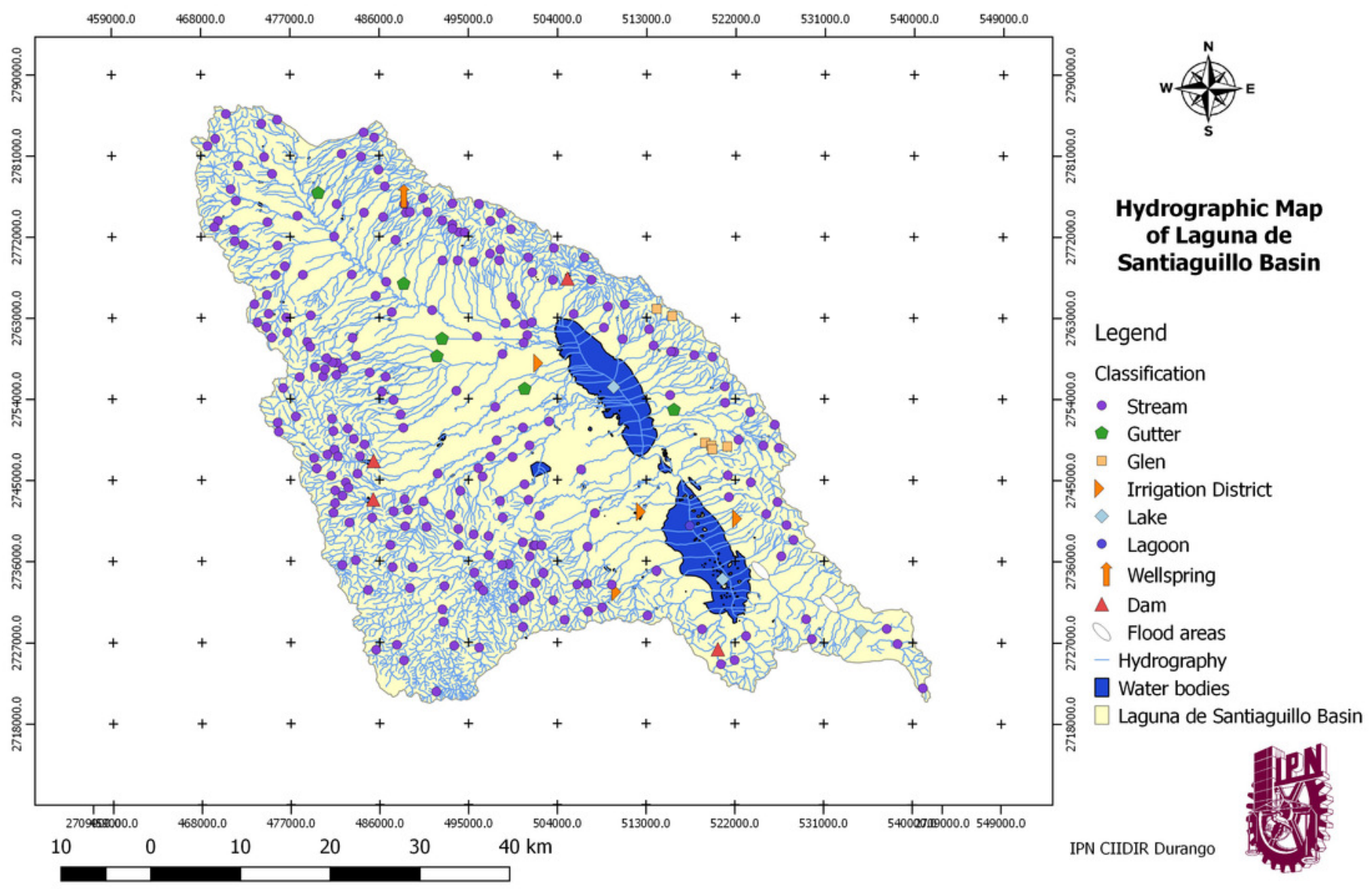


Figure 3

Map of hydrology surface and division in micro-watersheds

Map made with vector information of INEGI

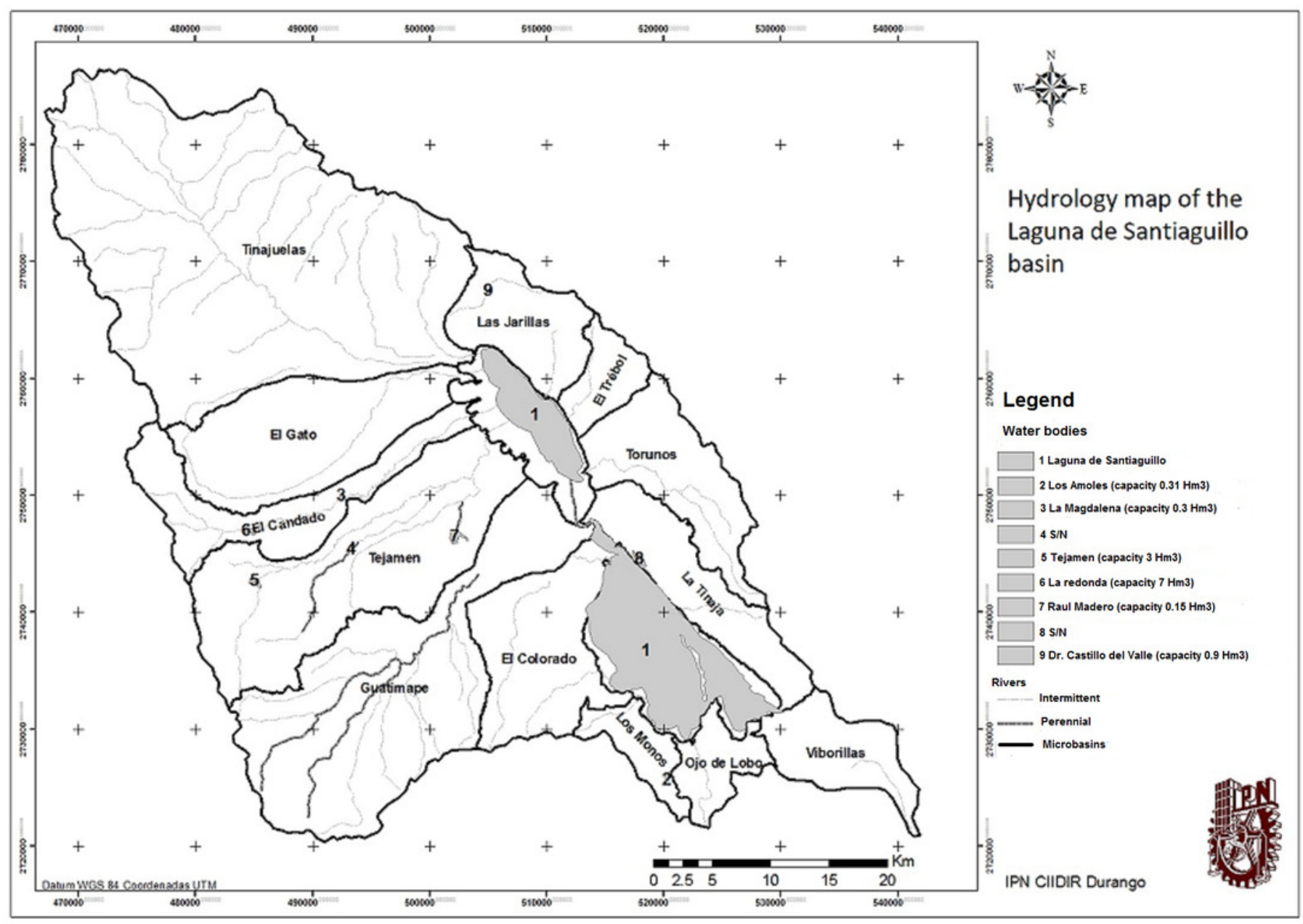


Figure 4

Population pyramid of the Laguna de Santiaguillo basin

Source: own elaboration with 2010 census information of INEGI

\section{Population pyramid}

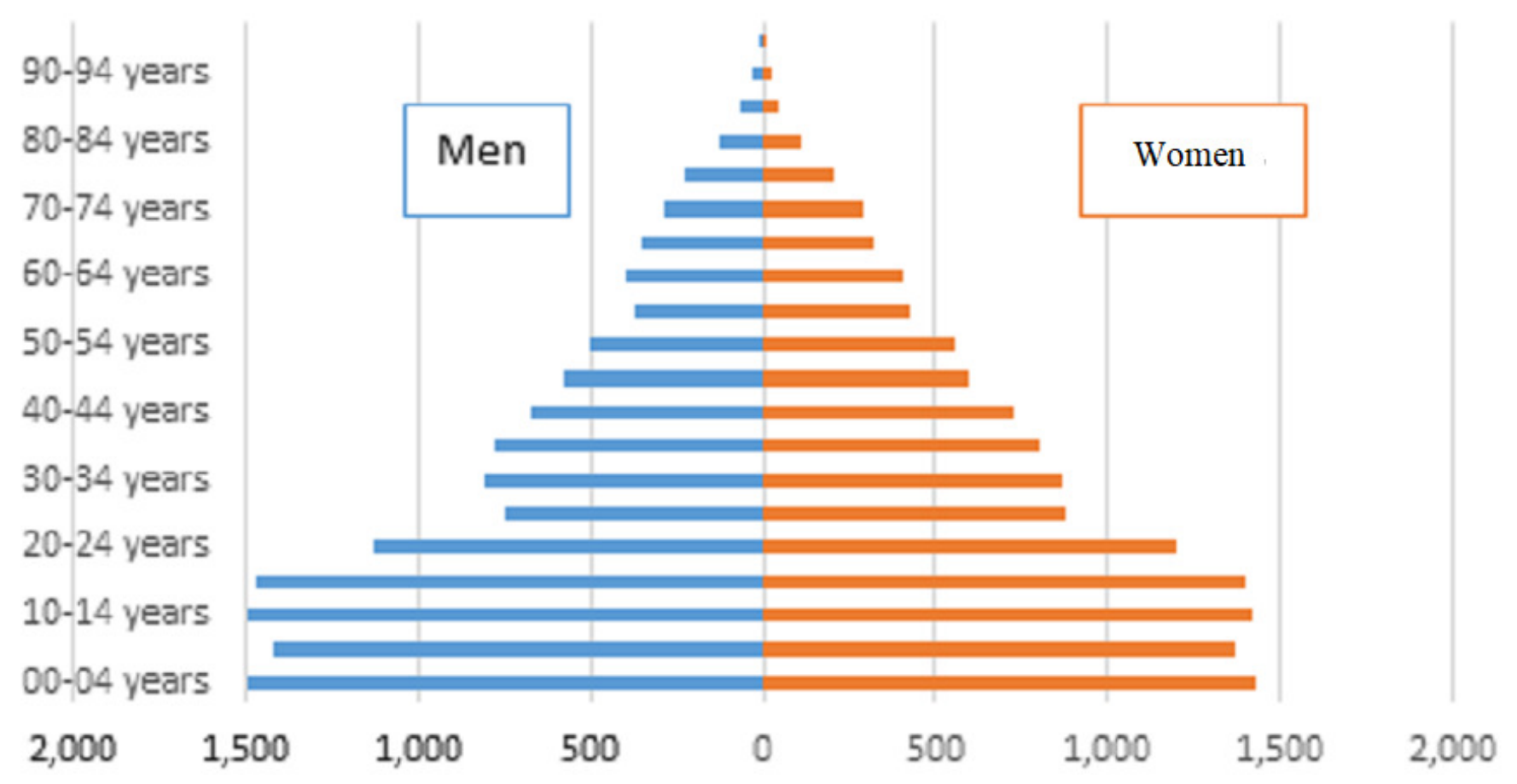


Figure 5

Land use for agriculture in the sub-basin

Map made with vector information of INEGI

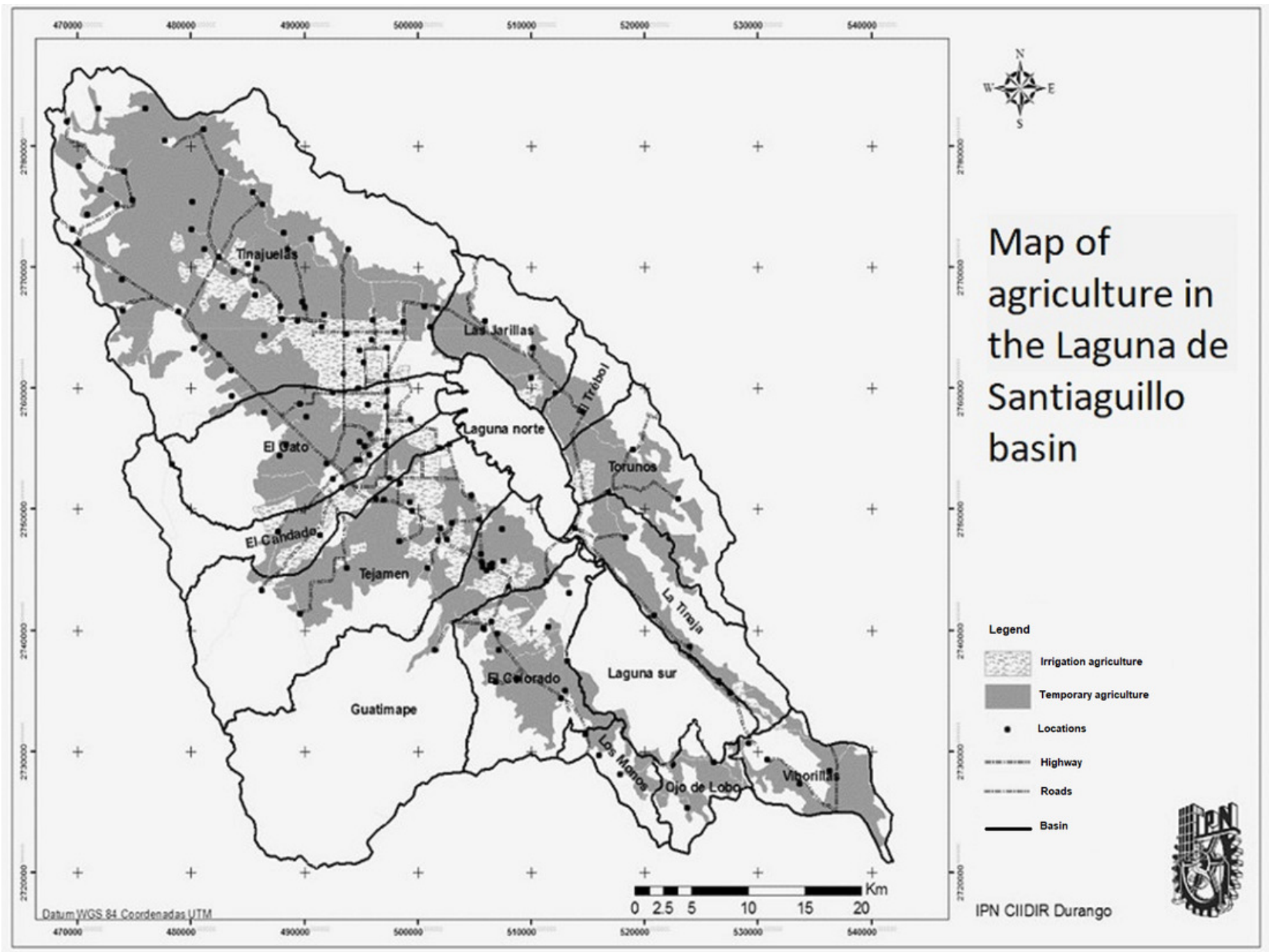


Figure 6

Use of groundwater in the Laguna de Santiaguillo basin (\%)

Made with CONAGUA Information

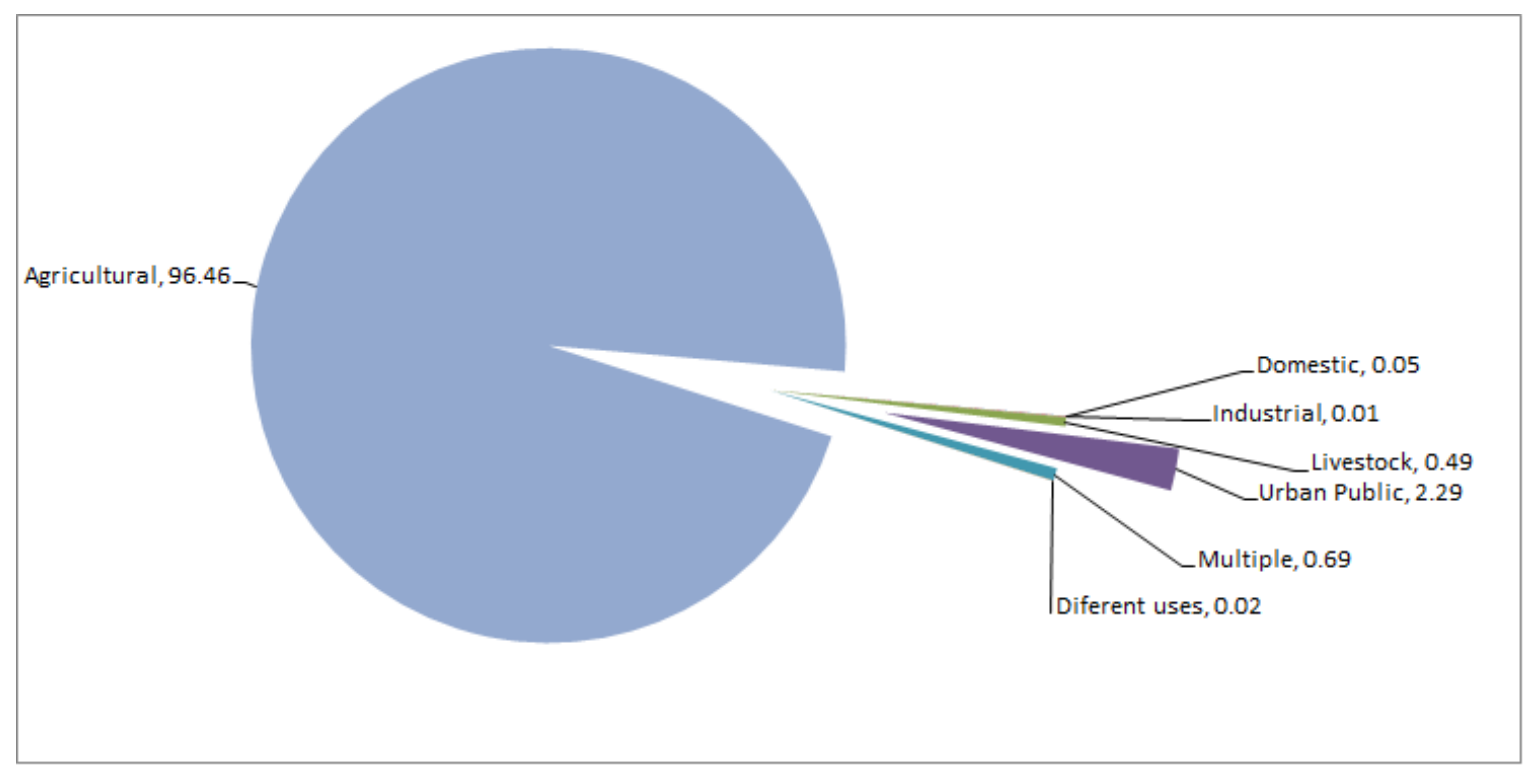


Figure 7

Map of aquifer overexploitation by micro-basins

Overexploitation by micro-basins

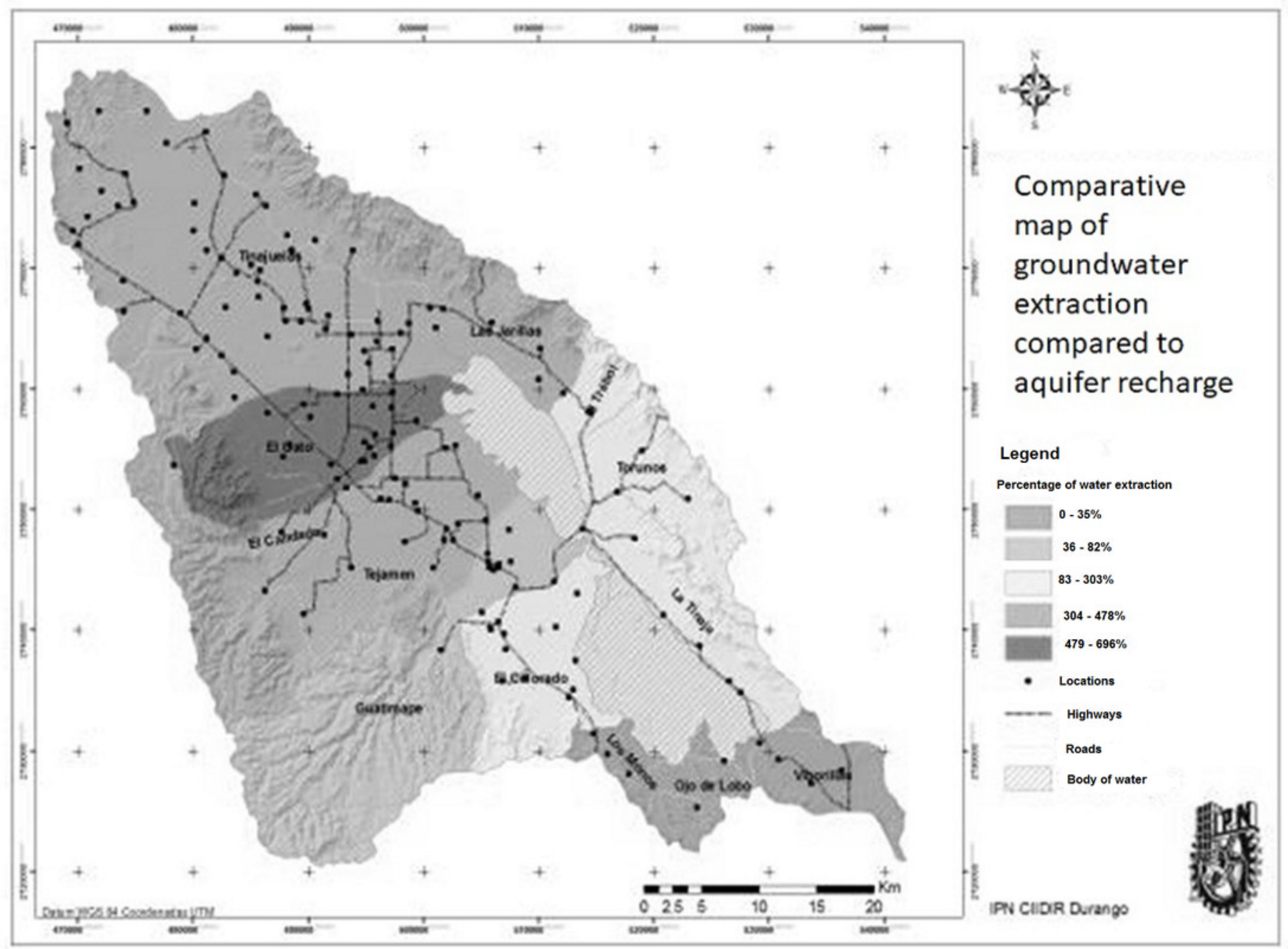


Figure 8

Comparison of extraction reduction scenarios against overexploitation of the aquifer

Comparison of extraction reduction scenarios

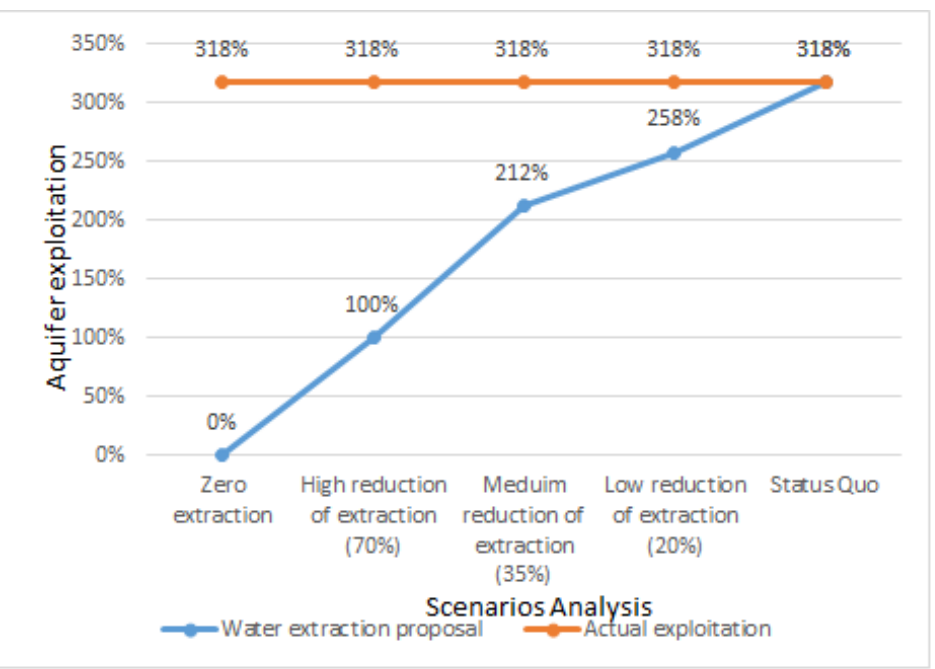

